\title{
Influence of process conditions on product yield of waste tyre pyrolysis- A review
}

\author{
Prakash Parthasarathy, Hang Seok Choi ${ }^{\dagger}$, Hoon Chae Park, Jae Gyu Hwang, Ho Seong Yoo, \\ Byeong-Kyu Lee, and Mukesh Upadhyay
}

\author{
Clean Energy Conversion Process Laboratory (CECP), Department of Environmental Engineering, \\ Yonsei University, Wonju, Gangwon-do 26493, Korea \\ (Received 3 February 2016 • accepted 2 May 2016)
}

\begin{abstract}
Waste tyres have become a grave concern as their accumulation is aggregating every year. Not only the size of waste tyre has to be reduced, but also some useful energy has to be recovered out of it as the world badly requires energy from alternate sources. Pyrolysis is one such method to extract energy potential products from waste tyres. It is extensively used to generate carbon black (solid product), tyre-oil (liquid product) and syngas (gas product) from waste tyres. In that connection, this article discusses the effect of various parameters on the product composition of pyrolysis of waste tyres. The current usage of pyrolysis products and their typical characteristics are also discussed in this critique. Of late, extraction of high value added products, such as activated carbon from carbon black, and limonene from tyre-oil is gaining attention. The article also throws some light on the application and generation routes of activated carbon and limonene from waste tyres.
\end{abstract}

Keywords: Waste Tyre, Pyrolysis, Carbon Black, Tyre-oil, Limonene

\section{INTRODUCTION}

\section{Scenario of Waste Tyre Accumulation}

It cannot be over-emphasized that the advancement of science and technology has made daily lives easy and comfortable. However, the impact of this advancement on the environment is worrying. The usage of polymers and the progress in the polymer industry has been generating more scrap plastics, rubbers, tyres, etc. [1]. The production of plastics, rubbers and tyres cannot be halted or reduced as its need and demand is increasing day by day. However, the life period and performance of these goods can be prolonged. Furthermore, as these scraps are increasingly dumped; a suitable means of utilizing these wastes should be explored. Though these wastes are engaged in the recycling process, its proportion is meager considering the amount of accumulation of these scraps [2]. Hence, an appropriate mode of treating of these wastes in the context of energy recovery should be explored as the need for energy is doubling up. Thus, the need is to find out a way to recover useful energy from these wastes with minimal damage to the surroundings.

It has been estimated that every year 1.5 billion waste tyres are discarded all over the world $[3,4]$. Of that, only $15-20 \%$ of that waste is taken for reuse [5]. The remaining $75-80 \%$ of waste tyres are simply dumped into the earth. It is quite likely that this figure will shoot up as the demand for tyres is increasing every year. Particularly in countries like the US, Japan, European Union (EU), Australia, South Africa and South Korea where the usage of automobiles is greater, the generation of scrap tyres is expected to in-

${ }^{\dagger}$ To whom correspondence should be addressed.

E-mail: hs.choi@yonsei.ac.kr

Copyright by The Korean Institute of Chemical Engineers. crease [6-8]. Some developing countries like China, India, Brazil, Taiwan and Indonesia are also greatly contributing to the accumulation of waste tyres [9].

\section{Problems of Scrap Tyres}

Vulcanization is done on tyres to increase their flexibility. Antioxidants and anti-ozonants are added to tyres to extend their life time. It's because of the vulcanization process and addition of antioxidants and anti-ozonants that tyres are non-degradable [10]. Hence, waste tyres accumulate in large piles, often to be either incinerated or landfilled. When incinerated openly, they release toxic gases, which are prone to cause cancer and mutation disorder [1113]. Strict pollution regulations all over the world have forced tyre incineration to operate in a closed system. However, closed incineration requires expensive air emission monitoring and control system.

Seventy-five \% of a tyre is void space [14]. Hence, amassing of tyres occupies a large amount of valuable work space. Also, landfilled tyres react with methane gas and form a reactive mixture that can percolate inside the soil and pollute both soil and water. The waste tyres also become breeding sites for mosquitoes $[15,16]$. Mosquitoes, in-fact, are the carriers of many dreadful diseases like dengue, chickengunya, elephantiasis and malaria as well as viruses like Zika. These landfilled tyres also pose a high risk of fire [2,10,17-19]. Although waste tyres cannot be ignited easily, when ignited they are difficult to extinguish. Here are some examples of serious fire mishaps that have occurred due to landfilled tyres: Rhinehart tyre fire of Virginia, USA in 1983, the great Kuwait tyre fire of Jahra, Kuwait in 2012, the Watertown tire fire of Wisconsin, USA in 2005 and the Westley tire fire of California, USA in 1999. It took several months to put out these fires. Not only did the waste tyre fire pollute the atmosphere, but it was also reported that water bodies in the nearby vicinity were contaminated with lead and arsenic. 
That illustrates the seriousness of waste tyre fires.

\section{Recycling of Waste Tyres}

Waste tyres are commonly incinerated to generate electricity, and in some cases to generate process steam. The steam is also used to heat and air-condition buildings [2]. In industries such as cement, steel and paper, waste tyres are used as a secondary fuel with coal. Researches on co-treatment of waste tyres with coal in power plants are also underway [20].

Apart from generation of useful heat, waste tyres are also recycled for other purposes. Since waste tyres have good acoustical properties they are used as sound proofing materials. They are also used as flooring medium in the construction of indoor stadiums, pavements etc. [21]. They are also employed in the laying of road and rail foundations [22].
Of all the recycling methods, reclaiming of tyres is the most environmentally benign mode of tyre reuse [9]. Reclamation is the process of recovering useful materials from the waste. Waste tyres are shredded into fines and are mixed with some reclaiming agents to yield reclaimed tyres. Nonetheless, it is reported that only $5 \%$ of the total waste tyres is reclaimed [2,23]. Even though the waste tyres are used for various applications as discussed above, the proportion of waste tyres employed for recycling is insignificant. The above applications are also restricted by limited market demand for the recycled goods.

\section{CHARACTERISTICS OF WASTE TYRES}

The typical composition of various tyres is provided in Table 1

Table 1. Typical composition of various tyres

\begin{tabular}{llllll}
\hline \hline Components & Tyre 1 & Tyre 2 & Tyre 3 & Tyre 4 & \multicolumn{1}{c}{ Tyre 5 } \\
composition (wt\%) & composition (wt\%) & $\begin{array}{l}\text { composition (wt\%) } \\
\text { composition (wt\%) }\end{array}$ & composition (wt\%) \\
\hline Rubber & 38.0 & 50.5 & 50.0 & 51.0 & 62.1 \\
Fillers & 30.0 & 25.5 & 25.0 & 26.0 & 31.0 \\
Reinforcing agents & 16.0 & 13.4 & 10.0 & Small amount & Small amount \\
Plasticizers & 10.0 & 5.5 & Small amount & 13.0 & 1.9 \\
Vulcanization agents & 4.0 & & 2.0 & 3.0 & 3.0 \\
Antioxidants & 1.0 & & Small amount & Small amount & Small amount \\
Miscellaneous substances & 1.0 & 4.7 & Small amount & 7.0 & 1.9 \\
\hline Reference & Nkosi and Muzenda [24], JATMA [25] & Aranda et al. [26] & Bajus and Olahová Amari et al. [28] & A27] \\
& Muzenda [10] & & & & \\
\hline
\end{tabular}

Table 2. Typical elemental and proximate analysis composition of biomass, coal and various tyres

\begin{tabular}{|c|c|c|c|c|c|c|c|}
\hline \multirow{2}{*}{ Elements } & Biomass & $\begin{array}{l}\text { Coal } \\
\text { (Anthracite) }\end{array}$ & Tyre 1 & Tyre 2 & Tyre 3 & Tyre 4 & Tyre 5 \\
\hline & $\begin{array}{l}\text { Composition } \\
\left(\mathrm{wt} \%{ }^{*}\right)\end{array}$ & $\begin{array}{l}\text { Composition } \\
\left(\text { wt } \%{ }^{*}\right)\end{array}$ & $\begin{array}{l}\text { Composition } \\
\left(\mathrm{wt} \%{ }^{*}\right)\end{array}$ & $\begin{array}{l}\text { Composition } \\
\left(\mathrm{wt} \%{ }^{*}\right)\end{array}$ & $\begin{array}{l}\text { Composition } \\
\left(\text { wt } \%{ }^{*}\right)\end{array}$ & $\begin{array}{l}\text { Composition } \\
\left(\mathrm{wt} \%{ }^{*}\right)\end{array}$ & $\begin{array}{l}\text { Composition } \\
\left(\text { wt } \%{ }^{*}\right)\end{array}$ \\
\hline Carbon & $38.00-57.00$ & 91.80 & 86.40 & 85.03 & 77.30 & 77.22 & 85.16 \\
\hline Hydrogen & $5.00-6.50$ & 1.40 & 8.00 & 7.65 & 6.20 & 6.72 & 7.27 \\
\hline Nitrogen & $0.00-1.00$ & 0.60 & 0.50 & 0.47 & 0.60 & 1.44 & 0.38 \\
\hline Oxygen & $35.00-46.00$ & 5.30 & 1.70 & 5.25 & 7.10 & 1.08 & 0.54 \\
\hline Sulphur & $0.00-0.10$ & 0.90 & 2.40 & 1.60 & 1.80 & 1.34 & 2.30 \\
\hline Reference & Basu [29] & Liu [35] & $\begin{array}{l}\text { Nkosi and Muzenda } \\
\text { [24], Muzenda [10] }\end{array}$ & $\begin{array}{l}\text { Aranda et al. } \\
{[26]}\end{array}$ & $\begin{array}{l}\text { Portofino } \\
\text { et al. [30] }\end{array}$ & $\begin{array}{c}\text { Gu et al. } \\
{[31]}\end{array}$ & $\begin{array}{l}\text { Galvagno } \\
\text { et al. [32] }\end{array}$ \\
\hline \multirow{2}{*}{ Elements } & Biomass & $\begin{array}{l}\text { Coal } \\
\text { (Anthracite) }\end{array}$ & Tyre 1 & Tyre 2 & Tyre 3 & Tyre 4 & Tyre 5 \\
\hline & $\begin{array}{l}\text { Composition } \\
\left(\text { wt } \%{ }^{*}\right)\end{array}$ & $\begin{array}{l}\text { Composition } \\
\left(\text { wt } \%{ }^{*}\right)\end{array}$ & $\begin{array}{l}\text { Composition } \\
\left(\mathrm{wt} \%{ }^{*}\right)\end{array}$ & $\begin{array}{l}\text { Composition } \\
\left(\mathrm{wt} \%{ }^{*}\right)\end{array}$ & $\begin{array}{l}\text { Composition } \\
\left(\text { wt } \%{ }^{*}\right)\end{array}$ & $\begin{array}{l}\text { Composition } \\
\left(\mathrm{wt} \%{ }^{*}\right)\end{array}$ & $\begin{array}{l}\text { Composition } \\
\left(\text { wt }{ }^{*}\right)\end{array}$ \\
\hline Moisture & 4.00 & 3.30 & 1.30 & 0.64 & 1.16 & 0.70 & 0.71 \\
\hline Volatile matter & 70.40 & 4.00 & 62.10 & 64.46 & 61.30 & 62.60 & 62.58 \\
\hline Fixed carbon & 21.40 & 53.70 & 29.40 & 30.02 & 33.47 & 30.10 & 30.07 \\
\hline Ash & 4.20 & 39.00 & 7.10 & 4.88 & 4.36 & 6.60 & 6.64 \\
\hline Reference & Basu [29] & Lee et al. [36] & $\begin{array}{l}\text { Nkosi and Muzenda } \\
{[24], \text { Muzenda [10] }}\end{array}$ & $\begin{array}{l}\text { Aranda et al. } \\
{[26]}\end{array}$ & $\begin{array}{l}\text { Galvagno et al. } \\
\text { [32] }\end{array}$ & $\begin{array}{l}\text { Martínez } \\
\text { et al. [33] }\end{array}$ & $\begin{array}{l}\text { Aylón et al. } \\
\text { [34] }\end{array}$ \\
\hline
\end{tabular}

${ }^{*}$ Moisture and ash free basis 
[10,24-28]. Rubber is the main component in tyres. Both natural and artificial rubbers are used for tyre manufacturing. Fillers such as carbon black, carbon chalk are added to impart color to the tyres. Carbon black is also used to remove heat from the tread and belt to minimize thermal damage to tyres. Some reinforcing materials like steel, rayon and nylon are added to provide support and strength to the tyre components. Plasticizers such as oils and resins are added for the easy shaping and molding of tyres. Sulfur, zinc oxide and some chemicals are added as vulcanizing agent. These agents improve elasticity and offer strength, hardness to tyres. Antioxidants are added to avoid separation of tread and belt during the long run of tyres.

The typical elemental and proximate analysis composition of biomass, coal and various tyres is given in Table 2 [10,24,26,29-36].
Tyres predominantly consist of nearly $86 \%$ of carbon. This indicates their high calorific value. Appreciable amount of hydrogen indicates that tyres contain more volatile content. The nitrogen and

Table 3. Comparison of calorific value of tyres with some common fuels

\begin{tabular}{lc}
\hline \hline Fuel & Higher heating value $(\mathrm{MJ} / \mathrm{kg})$ \\
\hline Waste tyre & $28.0-38.0$ \\
Anthracite coal & 34.0 \\
Diesel & 43.4 \\
Gasoline & 44.4 \\
Methane & 50.0 \\
\hline
\end{tabular}

Table 4. Analysis pertaining to tyres, carbon-black and tyre-oil

\begin{tabular}{|c|c|c|}
\hline Analysis & Standard & Referred test method \\
\hline Elemental analysis & ASTM D3176-89 & Standard practice for ultimate analysis of coal and coke \\
\hline Heating value & ASTM D2015-96 & $\begin{array}{l}\text { Standard test method for gross calorific value of coal and coke by } \\
\text { the adiabatic bomb calorimeter }\end{array}$ \\
\hline \multirow[t]{3}{*}{ Proximate } & ASTM D3173-87 & $\begin{array}{l}\text { Standard test method for moisture in the analysis sample of coal } \\
\text { and coke }\end{array}$ \\
\hline & ASTM D 3174-04 (2010) & $\begin{array}{l}\text { Standard test method for ash in the analysis sample of coal and } \\
\text { coke from coal }\end{array}$ \\
\hline & ASTM D3175-07 & $\begin{array}{l}\text { Standard test method for volatile matter in the analysis sample of } \\
\text { coal and coke }\end{array}$ \\
\hline $\begin{array}{l}\text { Rubber identification by pyrolysis } \\
\text { gas chromatography }\end{array}$ & ASTM D3452-93(1988) & $\begin{array}{l}\text { Standard practice for rubber-identification by pyrolysis-gas chro- } \\
\text { matography }\end{array}$ \\
\hline Sulfur content & ASTM D-1619-03 & Standard test methods for carbon black-sulfur content \\
\hline \multicolumn{3}{|l|}{ Analysis pertaining to carbon black } \\
\hline Analysis & Standard & Referred test method \\
\hline Elemental analysis & ASTM D3176-89 & Standard practice for ultimate analysis of coal and coke \\
\hline Heating value & ASTM D2015-96 & $\begin{array}{l}\text { Standard test method for gross calorific value of coal and coke by } \\
\text { the adiabatic bomb calorimeter }\end{array}$ \\
\hline \multirow[t]{3}{*}{ Proximate } & ASTM D3173-87 & $\begin{array}{l}\text { Standard test method for moisture in the analysis sample of coal } \\
\text { and coke }\end{array}$ \\
\hline & ASTM D 3174-04 (2010) & $\begin{array}{l}\text { Standard test method for ash in the analysis sample of coal and } \\
\text { coke from coal }\end{array}$ \\
\hline & ASTM D3175-07 & $\begin{array}{l}\text { Standard test method for volatile matter in the analysis sample of } \\
\text { coal and coke }\end{array}$ \\
\hline Carbon black-Ash content & ASTM D-1506-99 & Standard test methods for carbon black-ash content \\
\hline Pelleted- Pour density & ASTM D 1513-05 & Standard test method for carbon black, pelleted-pour density \\
\hline $\begin{array}{l}\text { Extractable transmittance } \\
\text { of toluene extract }\end{array}$ & ASTM D1618-99 (2011) & $\begin{array}{l}\text { Standard test method for carbon black extractable transmittance } \\
\text { of toluene extract }\end{array}$ \\
\hline $\begin{array}{l}\text { Mass loss of the pyrolytic and } \\
\text { commercial carbon black }\end{array}$ & ASTM D-1509-95 (2007) & Standard test methods for carbon black- heating loss \\
\hline Oil adsorption number & ASTM D 2414-11 & $\begin{array}{l}\text { Standard test method for carbon black- oil absorption number } \\
\text { (OAN) }\end{array}$ \\
\hline $\mathrm{pH}$ value & ASTM D 1512-15 & Standard test methods for carbon black- $\mathrm{pH}$ value \\
\hline Sieve residue & ASTM D-1514-01 & Standard test method for carbon black- sieve residue \\
\hline Oil absorption number (OAN) & ASTM D 2414-96 & $\begin{array}{l}\text { Standard test method for carbon black- oil absorption number } \\
\text { (OAN) }\end{array}$ \\
\hline Tint strength & ASTM D-3265-11 & Standard test method for carbon black- tint strength \\
\hline
\end{tabular}


Table 4. Continued

\begin{tabular}{|c|c|c|}
\hline \multicolumn{3}{|l|}{ Analysis pertaining to tyre-oil } \\
\hline Properties & Standards & Referred test method \\
\hline Acid number & ASTM D664-11a & $\begin{array}{l}\text { Standard test method for acid number of petroleum products by } \\
\text { potentiometric titration }\end{array}$ \\
\hline Aromatic hydrocarbons & ASTM D6591 - 11 & $\begin{array}{l}\text { Standard test method for determination of aromatic hydrocarbon } \\
\text { types in middle distillates- high performance liquid chromatog- } \\
\text { raphy method with refractive index detection }\end{array}$ \\
\hline Ash content & ASTM D482-03 & Standard test method for ash from petroleum products \\
\hline Boiling range distribution & ASTM D2887-15 & $\begin{array}{l}\text { Standard test method for boiling range distribution of petroleum } \\
\text { fractions by gas chromatography }\end{array}$ \\
\hline Calorific value & ASTM D240-09 & $\begin{array}{l}\text { Standard test method for heat of combustion of liquid hydrocar- } \\
\text { bon fuels by bomb calorimeter }\end{array}$ \\
\hline Carbon Conradson residue & ASTM D524-04 & $\begin{array}{l}\text { Standard test method for ramsbottom carbon residue of petro- } \\
\text { leum products }\end{array}$ \\
\hline Carbon residue & ISO 10370: 2014 & Determination of carbon residue by micro method \\
\hline Cetane index & ASTM D976-91 & Standard test methods for calculated cetane index of distillate fuels \\
\hline Cetane number & ASTM D7668-10 & $\begin{array}{l}\text { Standard test method for determination of derived cetane num- } \\
\text { ber (DCN) of diesel fuel oils-ignition delay and combustion } \\
\text { delay using a constant volume combustion chamber method }\end{array}$ \\
\hline Chrome & ASTM D5185-05 & $\begin{array}{l}\text { Standard test method for determination of additive elements, wear } \\
\text { metals, and contaminants in used lubricating oils and determi- } \\
\text { nation of selected elements in base oils by inductively coupled } \\
\text { plasma atomic emission spectrometry (ICP-AES) }\end{array}$ \\
\hline Cold filter plugging point & ASTM D6371-05 (2010) & $\begin{array}{l}\text { Standard test method for cold filter plugging point of diesel and } \\
\text { heating fuels }\end{array}$ \\
\hline Colour & ASTM D 1500-12 & $\begin{array}{l}\text { Standard test method for ASTM color of petroleum products } \\
\text { (ASTM color scale) }\end{array}$ \\
\hline Density & $\begin{array}{l}\text { ASTM-D1298-85 } \\
(1990) \text { e1 }\end{array}$ & $\begin{array}{l}\text { Standard practice for density, relative density (specific gravity), or } \\
\text { API gravity of crude petroleum and liquid petroleum products } \\
\text { by hydrometer method }\end{array}$ \\
\hline $\begin{array}{l}\text { Density, relative density } \\
\text { (specific gravity) or API } \\
\text { gravity }\end{array}$ & ASTM D1298-99 & $\begin{array}{l}\text { Standard test method for density, relative density (specific gravity), } \\
\text { or API gravity of crude petroleum and liquid petroleum prod- } \\
\text { ucts by hydrometer method }\end{array}$ \\
\hline Distillation & ASTM-D86-12 & $\begin{array}{l}\text { Standard test method for distillation of petroleum products at } \\
\text { atmospheric pressure }\end{array}$ \\
\hline Distillation characteristics & EN ISO 3405:2011 & $\begin{array}{l}\text { Determination of distillation characteristics of petroleum prod- } \\
\text { ucts at atmospheric pressure }\end{array}$ \\
\hline Elemental analysis & ASTM D5291-96 & $\begin{array}{l}\text { Standard test methods for instrumental determination of carbon, } \\
\text { hydrogen, and nitrogen in petroleum products and lubricants }\end{array}$ \\
\hline Flash point & ASTM D92-01 & $\begin{array}{l}\text { Standard test method for flash and fire points by Cleveland open } \\
\text { cup }\end{array}$ \\
\hline $\begin{array}{l}\text { Gas chromatography }(\mathrm{GC}) \\
\text { conditions for simulated } \\
\text { distillation }\end{array}$ & ASTM D2887-89 & $\begin{array}{l}\text { Standard simulated distillation protocol for the separation of petro- } \\
\text { leum fractions over the boiling points range of } 55.5 \text { to } 538^{\circ} \mathrm{C}\end{array}$ \\
\hline
\end{tabular}

sulfur content of tyres is comparatively higher than biomass, however lower than some high sulfur coals. Tyres contain a significant proportion of volatiles, which indicates that upon thermal decomposition a considerable yield of tyre-oil could be obtained. Significant quantity of fixed carbon indicates that tyres possess considerable heating value potential. Small ash content of tyres indicates that they have limited inorganic inert, which can be easily disposed, upon thermal degradation.

Heating value of some common fuels is presented in Table 3 [5]. Tyres have a heating value greater than the best quality coal. Hence, the co-combustion of tyres with low grade coal offers a tremendous scope. However, the heating value of tyres is lower than of diesel, gasoline and methane. Analysis involved in the determination of properties of tyres is given in Table $4[4,13,37]$. 
Table 4. Continued

\begin{tabular}{|c|c|c|}
\hline \multicolumn{3}{|l|}{ Analysis pertaining to tyre-oil } \\
\hline Properties & Standards & Referred test method \\
\hline Insoluble & ASTM 893-05 & Standard test method for insoluble in used lubricating oils \\
\hline Iron, Nickel & ASTM D5185-05 & $\begin{array}{l}\text { Standard test method for determination of additive elements, wear } \\
\text { metals, and contaminants in used lubricating oils and determi- } \\
\text { nation of selected elements in base oils by inductively coupled } \\
\text { plasma atomic emission spectrometry (ICP-AES) }\end{array}$ \\
\hline Karl Fischer water & ASTM D6304-07 & $\begin{array}{l}\text { Standard test method for determination of water in petroleum } \\
\text { products, lubricating oils, and additives by Coulometric Karl } \\
\text { Fischer titration }\end{array}$ \\
\hline Kinematic viscosity & ASTM D445-65 & $\begin{array}{l}\text { Standard method of test for viscosity of transparent and opaque } \\
\text { liquids (kinematic and dynamic viscosities) }\end{array}$ \\
\hline Lubricity & ISO 12156-2:2007 & $\begin{array}{l}\text { Assessment of lubricity using the high-frequency reciprocating rig } \\
\text { (HFRR) }\end{array}$ \\
\hline Oxidation stability & EN 15751 & Oxidation stability of biodiesel \\
\hline Pour point & ASTM D97-05 & Standard test method for pour point of petroleum products \\
\hline Specific gravity & ASTM D4052-96 & $\begin{array}{l}\text { Standard test method for density and relative density of liquids by } \\
\text { digital density meter }\end{array}$ \\
\hline Sulfur content XRF & ASTM D5453-12 & $\begin{array}{l}\text { Standard test method for determination of total sulfur in light } \\
\text { hydrocarbons, spark ignition engine fuel, diesel engine fuel, and } \\
\text { engine oil by ultraviolet fluorescence }\end{array}$ \\
\hline TAN & ASTM D 664-11a & $\begin{array}{l}\text { Standard test method for acid number of petroleum products by } \\
\text { potentiometric titration }\end{array}$ \\
\hline Total Particles & EN 12662 & Determination of contamination in middle distillates \\
\hline $\begin{array}{l}\text { Water content- Coulometric } \\
\text { Karl Fischer Titration }\end{array}$ & ASTM D4928-12 & $\begin{array}{l}\text { Standard test method for water in crude oils by Coulometric Karl } \\
\text { Fischer titration }\end{array}$ \\
\hline $\begin{array}{l}\text { Water content- Volumetric } \\
\text { Karl Fischer method }\end{array}$ & ASTM E203-96 & $\begin{array}{l}\text { Standard test method for water using volumetric Karl Fischer } \\
\text { titration }\end{array}$ \\
\hline
\end{tabular}

\section{ENERGY RECOVERY FROM WASTE TYRES}

Currently, there are three modes of energy recovery from waste tyres [38]. All the three modes are concerned with thermal decomposition of waste tyres: Pyrolysis gasification and liquefaction.

Pyrolysis is the simplest method of converting waste tyres into useful products. Since there are three types of pyrolysis, such as slow, fast and flash, based on the demand of the products (carbon black, tyre-oil and syngas), a suitable pyrolysis mode has to be chosen.

In gasification, the impetus is given to convert waste tyre into more gaseous products. The gasifying agent can be air, $\mathrm{O}_{2}$, steam, $\mathrm{CO}_{2}$ or any mixture of these. The quality and the proportion of gaseous product yield largely depend on the gasifying agent. Factors such as temperature, heating rate, residence time, nature of feedstock, type of reactor also have a profound influence on the product distribution.

On the other hand, liquefaction focuses on decomposing waste tyre into liquid products. The process takes place at lower temperature in the presence of catalyst. Liquefaction can be done through pyrolysis, gasification and hydrothermal treatment. In hydrothermal processing, waste tyres are converted into oily substances by treating with water at a temperature between $300-350{ }^{\circ} \mathrm{C}$ for a pressure of 12-20 MPa for certain period of time [29].

The operating parameters of waste tyre pyrolysis, gasification and liquefaction are provided in Table $5[10,29,39]$. The choice of the these processes depends on the product demand. For generation of carbon black, slow pyrolysis can be preferred. If the intended product is syngas, then gasification is the best choice. For the want of liquid fuels, fast pyrolysis and liquefaction could be an ideal option. Yet, the selection of conversion processes also relies on the economics, market demand of product, environmental regulations, topography, resources of the place, manpower, etc. [40,41].

\section{PYROLYSIS}

Through pyrolysis, waste tyres can be converted into convenient solid, liquid and gaseous fuels. The solid residue or solid product is called 'carbon black'. The liquid product is referred to as 'tyre-oil'. The gaseous product is termed 'syngas'. The proportion of these products depends on various factors. Primarily, slow and fast pyrolysis is employed to convert waste tyres into useful products.

Fig. 1 presents schematics of waste tyre pyrolysis $[19,42]$. The pyrolysis setup entails a heating source, reactor, condensers and a gas collection system. Since the pyrolysis process has to be in an inert atmosphere, usually $\mathrm{N}_{2}$ gas is passed into the system before and after the pyrolysis process. The solid product of pyrolysis, carbon black, can be collected from the reactor. The volatiles which condense in the condensers are accumulated as tyre-oils. Based on 
Table 5. Operating conditions of the tyre conversion processes

\begin{tabular}{|c|c|c|c|c|c|}
\hline Variables & Slow pyrolysis & Fast pyrolysis & Flash pyrolysis & Gasification & Liquefaction \\
\hline Intended product & Carbon black & Tyre-oil & Tyre-oil & Syngas & Tyre-oil \\
\hline Temperature $\left({ }^{\circ} \mathrm{C}\right)$ & $300-600$ & $300-700$ & $350-600$ & $350-900$ & $250-330$ \\
\hline Pressure & $\begin{array}{c}\text { Atmospheric } \\
\text { pressure }\end{array}$ & $\begin{array}{c}\text { Atmospheric } \\
\text { pressure }\end{array}$ & $\begin{array}{c}\text { Atmospheric } \\
\text { pressure }\end{array}$ & $\begin{array}{c}\text { Atmospheric } \\
\text { pressure }\end{array}$ & 5-20 MPa \\
\hline Heating rate $\left({ }^{\circ} \mathrm{C} / \mathrm{min}\right)$ & $5-50$ & $15-50$ & $700-1,100^{\circ} \mathrm{C} / \mathrm{s}$ & High & Medium \\
\hline Particle size (mm) & $1-4$ & $\sim 4$ & $0.3-1.18$ & $0.4-2.0$ & $0.5-4.0$ \\
\hline Solid residence time (min) & $30-60$ & $15-60$ & $<1 \mathrm{~s}$ & $15-60$ & $60-120$ \\
\hline Gasifying agent & Not essential & Not essential & Not essential & Essential & Not essential \\
\hline Equivalence ratio & $0.14-0.18$ & $0.14-0.18$ & $0.14-0.18$ & $0.20-.40$ & $0.14-0.18$ \\
\hline Water requirement & Not essential & Not essential & Not essential & Not essential & Essential \\
\hline Catalyst & Not essential & $\begin{array}{l}\text { Not essential. } \\
\text { However, catalyst } \\
\text { improves oil yield } \\
\text { and quality }\end{array}$ & $\begin{array}{l}\text { Not essential. } \\
\text { However, catalyst } \\
\text { improves oil yield } \\
\text { and quality }\end{array}$ & $\begin{array}{l}\text { Not essential. } \\
\text { However, catalyst } \\
\text { improves gas yield }\end{array}$ & Essential \\
\hline Syngas composition & \multicolumn{3}{|c|}{$\mathrm{H}_{2} \mathrm{~S}, \mathrm{CO}, \mathrm{CO}_{2}, \mathrm{CH}_{4}$, alkanes, alkenes } & $\begin{array}{c}\mathrm{H}_{2}, \mathrm{CO}, \mathrm{CO}_{2}, \mathrm{CH}_{4}, \\
\text { ethane, ethylene } \\
\text { and acetylene }\end{array}$ & $\begin{array}{l}\mathrm{H}_{2}, \mathrm{CO}, \mathrm{CO}_{2}, \\
\quad \text { alkanes, alkenes } \\
\quad \text { and } \mathrm{H}_{2} \mathrm{~S}\end{array}$ \\
\hline
\end{tabular}

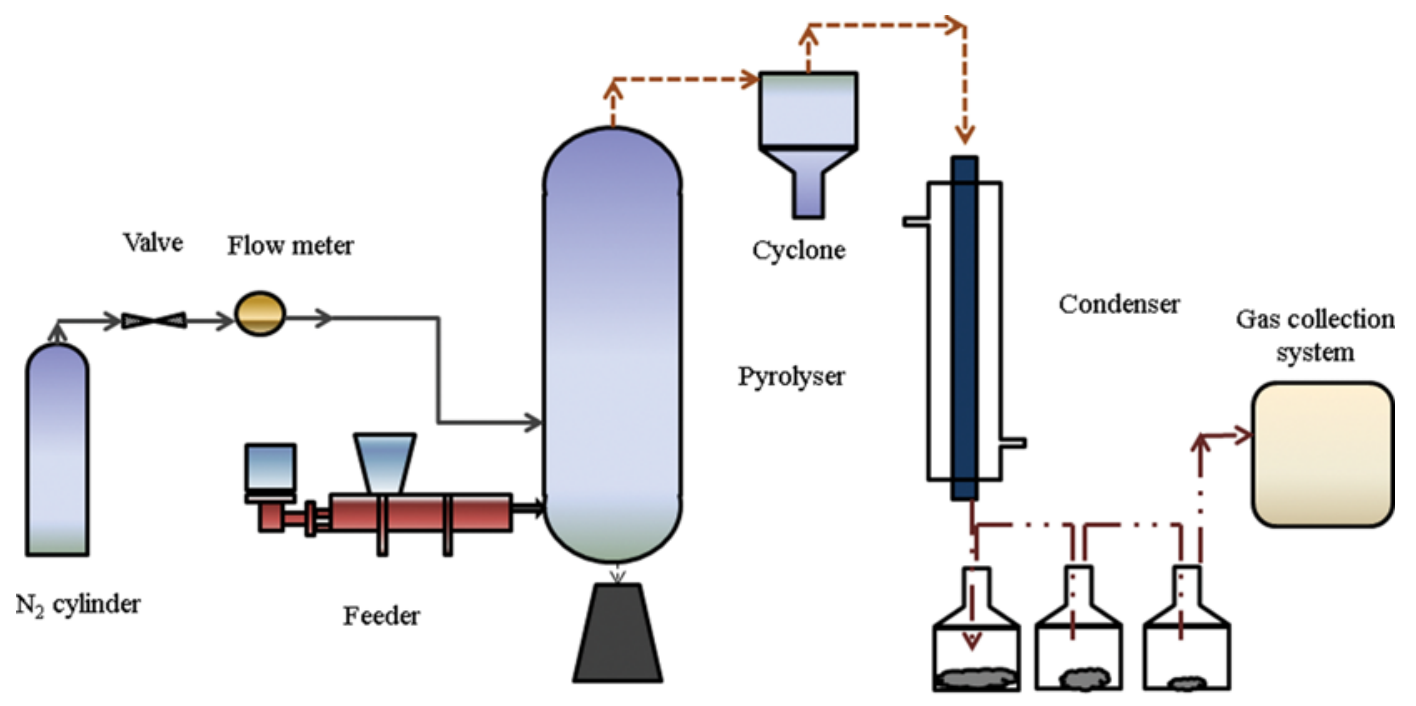

Char collector

Tyre-oil collection system

Fig. 1. Schematics of waste tyre pyrolysis.

the necessity of the process, either single condensers or multiple condensers are employed. The gases escaping from the condensers are collected in a suitable gas collection system.

Table 6 details some earlier works on the pyrolysis of waste tyres [19,43-45]. The table indicates that researchers have studied pyrolysis employing different reactors. The products of pyrolysis have been studied by varying parameters such as temperature, heating rate, feedstock particle size, solid residence time and catalyst.

Although a few articles focus on the influence of parameters on the products of waste tyre pyrolysis, they either focus on the aspect of generating tyre-oil or carbon-black $[7,21,46,47]$. Hence, in this article we present the effect of essential parameters such as temperature, heating rate, feedstock, feedstock particle size, residence time, reactor configuration and catalyst on all products of waste tyre pyrolysis. The emphasis is not on a single product but on all products: carbon black, tyre-oil and syngas. Also, we discuss the application of these pyrolysis products in various industries and their necessity in the near future. Further, the properties of all pyrolysis products and the analysis associated with it are well presented. We also emphasize the need to generate activated carbon from carbon black and to extract limonene from tyre-oil. The scope of activated carbon and limonene is also discussed.

\section{VARIABLES OF WASTE TYRE PYROLYSIS}

Temperature, heating rate, feedstock, particle size, residence time, 
Table 6. Previous works on pyrolysis of waste tyres

\begin{tabular}{|c|c|c|c|c|c|c|}
\hline Reactor & $\begin{array}{l}\text { Parameter of } \\
\text { study }\end{array}$ & $\begin{array}{l}\text { Operating } \\
\text { conditions }\end{array}$ & $\begin{array}{l}\text { Product } \\
\text { composition } \\
(\mathrm{wt} \%)\end{array}$ & Findings & Inference & Reference \\
\hline $\begin{array}{l}\text { Conical } \\
\text { bed } \\
\text { spouted } \\
\text { reactor }\end{array}$ & Temperature & $\begin{array}{l}\text { Feedstock- } 2 \mathrm{~g} \text { of } \\
\text { tyre, Temperature- } \\
425 \text { and } 500{ }^{\circ} \mathrm{C}\end{array}$ & $\begin{array}{l}\text { At } 400{ }^{\circ} \mathrm{C}: \text { Car- } \\
\text { bon black- } \\
\text { 35.0, Tyre-oil } \sim \\
\text { 64.0, Gas } \sim 1.0 \\
\text { At } 500{ }^{\circ} \mathrm{C} \text { : Car- } \\
\text { bon black- } \\
\text { 34.0, Tyre-oil } \sim \\
\text { 63.0, Gas } \sim 3.0\end{array}$ & $\begin{array}{c}\text { Increase in temperature } \\
\text { from } 425 \text { to } 500{ }^{\circ} \mathrm{C} \\
\text { decreased tar yield } \\
\text { from } 29.3 \text { to } 25.7 \%\end{array}$ & $\begin{array}{l}\text { Increase in pyrolysis } \\
\text { temperature } \\
\text { increases gas yield. } \\
\text { Increase in pyrolysis } \\
\text { temperature } \\
\text { reduces tar yield. }\end{array}$ & $\begin{array}{c}\text { Olazar et al. } \\
\text { [43] }\end{array}$ \\
\hline \multirow[t]{2}{*}{$\begin{array}{l}\text { Conical } \\
\text { bed } \\
\text { spouted } \\
\text { reactor }\end{array}$} & $\begin{array}{l}\text { Temperature } \\
\text { and Catalyst }\end{array}$ & $\begin{array}{l}\text { Feedstock- } 2 \mathrm{~g} \text { of } \\
\text { tyre, Catalyst- } \\
\text { HZSM5, Catalyst } \\
\text { quantity- } 15 \mathrm{~g} \text { cat- } \\
\text { alytic bed Tem- } \\
\text { perature- } 425 \text { and } \\
500^{\circ} \mathrm{C} \text {. }\end{array}$ & $\begin{array}{l}\text { At } 425^{\circ} \mathrm{C}: \text { Car- } \\
\text { bon black- } \\
\text { 34.0, Tyre-oil } \sim \\
\text { 58.0, Gas } \sim 8.0 \\
\text { At 500 }{ }^{\circ} \mathrm{C}: \text { Car- } \\
\text { bon black- } \\
\text { 45.0, Tyre-oil } \sim \\
\text { 35.0, Gas } \sim 20.0\end{array}$ & $\begin{array}{l}\text { In presence of HZSM5 } \\
\text { catalyst, increase in } \\
\text { temperature from } 425 \\
\text { to } 500{ }^{\circ} \mathrm{C} \text { increased } \\
\text { char yield from } 34.0 \text { to } \\
45.0 \% \text { and gas yield } \\
\text { from } 8.0 \text { to } 20.0 \% \\
\text { Addition of HZSM5 cat- } \\
\text { alyst decreased tar } \\
\text { yield significantly from } \\
28.8 \text { to } 14.9 \%\end{array}$ & $\begin{array}{l}\text { Introduction of } \\
\text { HZSM5 catalyst } \\
\text { reduces tar yield } \\
\text { drastically. } \\
\text { HZSM5 catalyst } \\
\text { encourages gas } \\
\text { yield. }\end{array}$ & $\begin{array}{l}\text { Olazar et al. } \\
\text { [43] }\end{array}$ \\
\hline & $\begin{array}{l}\text { Temperature } \\
\text { and Catalyst }\end{array}$ & $\begin{array}{l}\text { Feedstock- } 2 \mathrm{~g} \text { of } \\
\text { tyre, Catalyst- HY, } \\
\text { Catalyst quantity- } \\
15 \text { g catalytic bed, } \\
\text { Temperature- } 425 \\
\text { and } 500^{\circ} \mathrm{C}\end{array}$ & $\begin{array}{l}\text { At } 425^{\circ} \mathrm{C} \text { : Car- } \\
\text { bon black- } \\
\text { 33.0, Tyre-oil } \sim \\
\text { 64.0, Gas } ~ 3.0 \\
\text { At } 500{ }^{\circ} \mathrm{C} \text { : Car- } \\
\text { bon black- } \\
\text { 35.0, Tyre-oil } \sim \\
\text { 62.0, Gas } \sim 3.0\end{array}$ & $\begin{array}{l}\text { With the presence of } \mathrm{HY} \\
\text { catalyst, increase in } \\
\text { temperature from } 425 \\
\text { to } 500{ }^{\circ} \mathrm{C} \text {, slightly } \\
\text { increased carbon black } \\
\text { yield. However, a small } \\
\text { decrease in tyre-oil } \\
\text { yield from } 64.0 \text { to } \\
62.0 \% \text { was noted. With } \\
\text { respect to gas yield, no } \\
\text { change was observed. } \\
\text { With regard to tar yield, } \\
\text { increase in tempera- } \\
\text { ture from } 425 \text { to } \\
500{ }^{\circ} \mathrm{C} \text { significantly } \\
\text { reduced tar yield from } \\
42.7 \text { to } 32.5 \% \text {. }\end{array}$ & $\begin{array}{l}\text { HY catalyst induces } \\
\text { carbon black } \\
\text { yield. } \\
\text { Introduction of HY } \\
\text { catalyst signifi- } \\
\text { cantly reduces tar } \\
\text { yield. }\end{array}$ & \\
\hline
\end{tabular}

reactor configuration are some essential factors which decide the product distribution of pyrolysis [48-50]. The factors affecting the yield of tyre pyrolysis products are discussed in detail below.

\section{Effect of Temperature}

Temperature is the most influential factor on the product yield of pyrolysis. In general, low temperatures $\left(300-450^{\circ} \mathrm{C}\right)$ favor carbon black yield, medium temperatures $\left(450-600^{\circ} \mathrm{C}\right)$ support liquid yield, while high temperatures $\left(>600^{\circ} \mathrm{C}\right)$ tend to favor gas yield. Some works on the effect of temperature on product yield are discussed below.

Unapumnuk et al. studied the influence of temperature on carbon content of pyrolysis products of TDF in a laboratory scale pyrolysis reactor [13]. About 3-4 g TDF was taken for the study. An inert atmosphere was provided by supplying $\mathrm{N}_{2}$ at a flow rate of $0.47 \mathrm{ll}$ $\mathrm{min}$. The study was carried out at different temperatures of 600 , 800 and $1,000^{\circ} \mathrm{C}$, maintaining a heating rate of $5^{\circ} \mathrm{C} / \mathrm{min}$. Only the carbon content of carbon black and tyre-oil was determined; the carbon content in gas was calculated by mass balance. With the increase in temperature from 600 to $800{ }^{\circ} \mathrm{C}$, a decrease in carbon content of carbon black from 0.48 to $0.44 \mathrm{~g}$ (g denotes $\mathrm{g}$ of carbon in $1 \mathrm{~g}$ of TDF sample) was obtained. Beyond $800{ }^{\circ} \mathrm{C}$, the carbon content of carbon black remained constant. In the case of tyre-oil, an increase in temperature decreased the carbon content from 0.24 to $0.14 \mathrm{~g}$. For gas, an increase in temperature increased the gas yield from 0.07 to $0.22 \mathrm{~g}$. The carbon content was the highest in carbon black. Maximum carbon content of carbon black of 
Table 6. Continued

\begin{tabular}{|c|c|c|c|c|c|c|}
\hline Reactor & $\begin{array}{l}\text { Parameter of } \\
\text { study }\end{array}$ & $\begin{array}{l}\text { Operating } \\
\text { conditions }\end{array}$ & $\begin{array}{l}\text { Product } \\
\text { composition } \\
(\mathrm{wt} \%)\end{array}$ & Findings & Inference & Reference \\
\hline $\begin{array}{l}\text { Pyrex } \\
\text { glass } \\
\text { batch } \\
\text { reactor }\end{array}$ & Catalyst & $\begin{array}{l}\text { Temperature- } 350^{\circ} \mathrm{C} \text {, } \\
\text { Pressure- Atmo- } \\
\text { spheric condition, } \\
\text { Solid residence } \\
\text { time- } 2 \mathrm{hr} \text {, Cata- } \\
\text { lyst- } \mathrm{MgO} \& \\
\mathrm{CaCO}_{3}\end{array}$ & 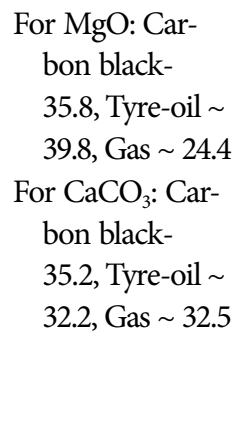 & $\begin{array}{l}\text { MgO catalyst favored } \\
\text { generation of tyre-oil } \\
\text { and yielded a maxi- } \\
\text { mum tyre-oil yield of } \\
39.8 \% \text {. } \\
\text { On the other hand, } \\
\mathrm{CaCO}_{3} \text { supported gen- } \\
\text { eration of gas and } \\
\text { yielded a maximum } \\
\text { gas yield of } 32.5 \% \text {. }\end{array}$ & $\begin{array}{l}\text { The } \mathrm{MgO} \text { catalyst is } \\
\text { effective for tyre- } \\
\text { oil generation } \\
\text { while } \mathrm{CaCO}_{3} \text { is } \\
\text { efficient for gas } \\
\text { yield. }\end{array}$ & $\begin{array}{c}\text { Shah et al. } \\
\text { [44] }\end{array}$ \\
\hline $\begin{array}{l}\text { Fixed bed } \\
\text { reactor }\end{array}$ & Temperature & $\begin{array}{l}\text { Feedstock- } 10 \mathrm{~g}, \\
\text { Heating rate- } \\
10^{\circ} \mathrm{C} / \mathrm{min} \text {, Atmo- } \\
\text { sphere- } \mathrm{N}_{2} \text {, Solid } \\
\text { residence time- } 60 \\
\text { min Temperature- } \\
375,400,425,450, \\
475 \text { and } 500^{\circ} \mathrm{C}\end{array}$ & $\begin{array}{l}\text { At } 375^{\circ} \mathrm{C}: \text { Car- } \\
\text { bon black- } \\
50.7, \text { Tyre-oil } \sim \\
46.2, \text { Gas } \sim 3.0 \\
\text { At } 400^{\circ} \mathrm{C}: \text { Car- } \\
\text { bon black- } \\
\text { 40.0, Tyre-oil } \sim \\
\text { 51.0, Gas } \sim 6.0 \\
\text { At } 425^{\circ} \mathrm{C}: \text { Car- } \\
\text { bon black- } \\
\text { 30.0, Tyre-oil } \sim \\
\text { 60.0, Gas } \sim 9.0 \\
\text { At } 450^{\circ} \mathrm{C}: \text { Car- } \\
\text { bon black- } \\
\text { 27.0, Tyre-oil } \sim \\
58.0, \text { Gas } \sim 12.0 \\
\text { At } 475^{\circ} \mathrm{C}: \text { Car- } \\
\text { bon black- } \\
\text { 26.4, Tyre-oil } \sim \\
57.0, \text { Gas } \sim 16.0 \\
\text { At 500 }{ }^{\circ} \mathrm{C}: \text { Car- } \\
\text { bon black- } \\
\text { 26.4, Tyre-oil } \sim \\
54.1, \text { Gas } \sim 20.2\end{array}$ & $\begin{array}{l}\text { Increase in temperature } \\
\text { from } 375 \text { to } 500{ }^{\circ} \mathrm{C} \\
\text { decreased char yield } \\
\text { from } 50.7 \text { to } 26.4 \% \text {. } \\
\text { Tyre-oil increased } \\
\text { from } 46.2 \text { to } 60.0 \% \\
\text { when the temperature } \\
\text { was increased from } \\
375 \text { to } 425^{\circ} \mathrm{C} \text {. None- } \\
\text { theless, when tempera- } \\
\text { ture was further } \\
\text { increased from } 425 \text { to } \\
500{ }^{\circ} \mathrm{C} \text {, a decrease in } \\
\text { tyre-oil yield from } 60.0 \\
\text { to } 54.1 \% \text { was noted. } \\
\text { Whilst, increase in } \\
\text { temperature from } 375 \\
\text { to } 500{ }^{\circ} \mathrm{C} \text { increased } \\
\text { gas yield from } 3.0 \text { to } \\
20.2 \% \text {. }\end{array}$ & $\begin{array}{l}\text { Maximum oil yield } \\
\text { is obtained at } \\
\text { medium pyrolysis } \\
\text { temperatures } \\
\left(425-450^{\circ} \mathrm{C}\right) .\end{array}$ & Kar [19] \\
\hline
\end{tabular}

$0.48 \mathrm{~g}$ was obtained at $600^{\circ} \mathrm{C}$. Maximum carbon content of tyreoil of $0.24 \mathrm{~g}$ was obtained at $600^{\circ} \mathrm{C}$. Maximum carbon content of gas of $0.22 \mathrm{~g}$ was obtained at $1,000^{\circ} \mathrm{C}$.

Pradhan and Singh investigated the effect of temperature on product yields [51]. Experiments were conducted using bicycle tyres in a batch reactor. The temperature effect was studied between 450 to $650^{\circ} \mathrm{C}$. A heating rate of $20^{\circ} \mathrm{C} / \mathrm{min}$ was maintained and a particle of size of $1 \mathrm{~cm}$ was considered. A significant decrease in carbon yield was obtained when the temperature was increased from 450 to $600^{\circ} \mathrm{C}$. However, after $600^{\circ} \mathrm{C}$ only a slight decrease in carbon black yield was observed. No significant difference in yield of carbon black was observed between 600 to $700{ }^{\circ} \mathrm{C}$. In case of tyretyre-oil, a steady increase in yield was noticed till $600^{\circ} \mathrm{C}$. However, above $600{ }^{\circ} \mathrm{C}$ no significant change in oil yield was observed. With the increase in temperature, there was a slight increase in gas yield till $550{ }^{\circ} \mathrm{C}$. However, after $600{ }^{\circ} \mathrm{C}$ the trend got reversed: only an increase in gas yield was noted. Maximum carbon black yield of $68.6 \%$ was obtained at $450{ }^{\circ} \mathrm{C}$. Maximum tyre-oil yield of $49.6 \%$ was observed at $600{ }^{\circ} \mathrm{C}$. Maximum gas yield of $11.5 \%$ was noted at $550{ }^{\circ} \mathrm{C}$.

From the above studies, it can be seen that increase in pyrolysis temperature decreases carbon black yield. In case of tyre-oil, initially an increase in temperature increases yield. Nonetheless, after a certain temperature the yield of tyre-oil decreases irrespective of the temperature increase. For gas, increase in temperature always increases the yield.

\section{Effect of Particle Heating Rate}

Next to temperature, the heating rate plays a vital role in controlling the product yield of pyrolysis. In general, when waste tyres are heated at a higher heating rate, it yields less carbon black; how- 
Table 6. Continued

\begin{tabular}{|c|c|c|c|c|c|c|}
\hline Reactor & $\begin{array}{l}\text { Parameter of } \\
\text { study }\end{array}$ & $\begin{array}{l}\text { Operating } \\
\text { conditions }\end{array}$ & $\begin{array}{l}\text { Product } \\
\text { composition } \\
(\mathrm{wt} \%)\end{array}$ & Findings & Inference & Reference \\
\hline $\begin{array}{l}\text { Fixed bed } \\
\text { reactor }\end{array}$ & Catalyst & $\begin{array}{l}\text { Feedstock- } 10 \mathrm{~g}, \\
\text { Temperature- } \\
375^{\circ} \mathrm{C} \text {, Heating } \\
\text { rate- } 10^{\circ} \mathrm{C} / \mathrm{min}, \\
\text { Atmosphere- } \mathrm{N}_{2} \text {, } \\
\text { Solid residence } \\
\text { time- } 60 \text { min, Cat- } \\
\text { alyst- Expanded } \\
\text { perlite, Catalyst } \\
\text { addition- } 5,10,15, \\
20 \text { and } 25 \%\end{array}$ & $\begin{array}{l}\text { For 5\% catalyst: } \\
\text { Carbon black- } \\
\text { 28.0, Tyre-oil } \sim \\
\text { 62.0, Gas } \sim 8.0 \\
\text { For 10\% catalyst: } \\
\text { Carbon black- } \\
\text { 27.0, Tyre-oil } \sim \\
\text { 65.0, Gas } \sim 8.0 \\
\text { For 15\% catalyst: } \\
\text { Carbon black- } \\
\text { 28.0, Tyre-oil } \sim \\
\text { 61.0, Gas } \sim 11.0 \\
\text { For 20\% catalyst: } \\
\text { Carbon black- } \\
\text { 27.0, Tyre-oil } \sim \\
\text { 59.0, Gas 18.0 } \\
\text { For 25\% catalyst: } \\
\text { Carbon black- } \\
\text { 27.0, Tyre-oil } \sim \\
\text { 58.0, Gas } \sim 19.0\end{array}$ & $\begin{array}{l}\text { At } 375^{\circ} \mathrm{C} \text {, addition of } \\
5 \% \text { expanded perlite } \\
\text { catalyst improved tyre- } \\
\text { oil yield from } 46.2 \text { to } \\
62.0 \% \text {, gas yield from } \\
3.0 \text { to } 8.0 \% \text {. Neverthe- } \\
\text { less, a decrease in char } \\
\text { yield from } 50.7 \text { to } \\
28.0 \% \text { was observed } \\
\text { with the addition of } \\
\text { catalyst. } \\
\text { Increase in catalyst com- } \\
\text { position from } 5 \text { to } \\
25 \% \text { did not change } \\
\text { the char yield. } \\
\text { In case of tyre-oil, } \\
\text { increase in catalyst } \\
\text { composition from } 5 \text { to } \\
10 \% \text { increased tyre oil } \\
\text { yield from } 62.0 \text { to } \\
65.0 \% \text {. However, fur- } \\
\text { ther increase in cata- } \\
\text { lyst composition } \\
\text { decreased oil yield. } \\
\text { This indicated that } \\
\text { with regard to tyre-oil } \\
\text { yield catalyst under- } \\
\text { went saturation after } \\
10 \% \text { catalyst composi- } \\
\text { tion. } \\
\text { With regard to gas yield, } \\
\text { increase in catalyst } \\
\text { composition from } 5 \text { to } \\
\text { yield from } 8.0 \text { to } 19 \% \text {. }\end{array}$ & $\begin{array}{l}\text { The introduction of } \\
\text { catalyst increases } \\
\text { tyre-oil and gas } \\
\text { yield while } \\
\text { decreasing car- } \\
\text { bon black yield. } \\
\text { The addition of cat- } \\
\text { alyst initially } \\
\text { increases oil yield. } \\
\text { However, the } \\
\text { effect of catalyst } \\
\text { saturates after cer- } \\
\text { tain composition } \\
\text { of catalyst. } \\
\text { Increase in composi- } \\
\text { tion of catalyst } \\
\text { drastically } \\
\text { improves gas } \\
\text { yield. }\end{array}$ & $\operatorname{Kar}[19]$ \\
\hline $\begin{array}{l}\text { Fluidized } \\
\text { bed }\end{array}$ & Temperature & $\begin{array}{l}\text { Pressure- } 101.325 \mathrm{~Pa} \text {, } \\
\text { Solid residence } \\
\text { time- } 12-20 \mathrm{~min} \\
\text { Temperature- } 350 \text {, } \\
500 \text { and } 600^{\circ} \mathrm{C} \text {. }\end{array}$ & $\begin{array}{c}\text { At } 350^{\circ} \mathrm{C}: \text { Tyre- } \\
\text { oil } \sim 42.0 \\
\text { At } 500{ }^{\circ} \mathrm{C}: \text { Tyre- } \\
\text { oil } \sim 38.0 \\
\text { At } 600^{\circ} \mathrm{C} \text { : Tyre- } \\
\text { oil } \sim 18.0\end{array}$ & $\begin{array}{l}\text { Increase in temperature } \\
\text { from } 350 \text { to } 600{ }^{\circ} \mathrm{C} \\
\text { decreased tyre-oil yield } \\
\text { from } 42.0 \text { to } 18.0 \% \text {. } \\
\text { Yield of tyre-oil was } \\
\text { significant }(38.0- \\
42.0 \%) \text { only at } \\
\text { medium temperatures } \\
\left(350-500^{\circ} \mathrm{C}\right) .\end{array}$ & $\begin{array}{l}\text { Yield of tyre-oil is } \\
\text { maximum at } \\
\text { medium pyrolysis } \\
\text { temperatures. }\end{array}$ & $\begin{array}{l}\text { Araki et al. } \\
\text { [45] }\end{array}$ \\
\hline
\end{tabular}

ever, it supports for more tyre-oil and gas yield.

The effect of heating rate on product yield was observed by Unapumnuk et al. [13]. The study was performed on tyre-derived fuels (TDF) in a laboratory scale pyrolysis reactor. TDF of quantity 3-4 g was fed into the reactor. $\mathrm{N}_{2}$ was supplied into the reactor to offer an inert atmosphere. The study looked at different heating rates of 1,5 and $10^{\circ} \mathrm{C} / \mathrm{min}$, varying temperatures between 400 to $1,000^{\circ} \mathrm{C}$. It was observed that the tyre-oil yield was highest at $\sim 550-600{ }^{\circ} \mathrm{C}$ for the heating rate of $5^{\circ} \mathrm{C} / \mathrm{min}$. The maximum tyre-oil yield was $0.4 \mathrm{~g} / \mathrm{g}$ of TDF sample. 
Su and Deng conducted TGA on Chinese waste tyre powder of particle size 100 mesh at three different heating rates, 10, 20 and $40^{\circ} \mathrm{C} / \mathrm{min}$, to study the pyrolysis characteristics of samples [5]. The experiment was conducted between room temperature to $800^{\circ} \mathrm{C}$ and at $\mathrm{N}_{2}$ atmosphere of flow rate $20 \mathrm{ml} / \mathrm{min}$. It was found that a high heating rate developed some resistance during pyrolysis. At high heating rates, the surface of particles liquefies and hinders the release of volatiles, and hence the pyrolysis process is affected at high heating rates. It was suggested to conduct pyrolysis at small heating rate to overcome heat resistance. It was also observed that initial temperature, final temperature and peak temperature for mass loss were comparatively low at $10^{\circ} \mathrm{C} / \mathrm{min}$. Initial temperatures correspond to the minimum temperature at which degradation of components starts. Final temperature corresponds to the temperature at which degradation of components undergoes completion. Peak temperature is the temperature at which maximum weight loss is occurring. The study indicates that at low heating rates initial, final and peak temperatures of components are low.

González et al. studied the effect of heating rate in shredded waste tyre pyrolysis [49]. Experiments were conducted in a cylindrical stainless steel atmospheric pressure reactor over a range of 350$700^{\circ} \mathrm{C}$ and at different heating rates of $5,10,15$ and $20 \mathrm{~K} / \mathrm{min}$. It was noted that with the increase in heating rate, a decrease in carbon black yield was observed. Liquid yield exhibited an increase when heating rate was increased up to $15 \mathrm{~K} / \mathrm{min}$. However, at $20 \mathrm{~K} /$ min a decrease in liquid yield was observed. On the other hand, a steady increase in gas yield was obtained when heating rate was increased. It was also noted that carbon black obtained at higher heating rate exhibited high surface area. Maximum carbon black yield of $40.9 \%$ was obtained at $5 \mathrm{~K} / \mathrm{min}$, maximum liquid yield of $55.4 \%$ was noted at $15 \mathrm{~K} / \mathrm{min}$, while maximum gas yield of $6.6 \%$ was observed at $20 \mathrm{~K} / \mathrm{min}$.

The above studies indicate that low heating rates favor carbon black yield, while high heating rates support gas yield. It can also be seen that at low heating rates effective decomposition of waste tyres is occurring.

\section{Feedstock}

Leung and Wang studied the kinetics of scrap tyre pyrolysis and combustion using TG and DT analysis [52]. Three materials, such as tyre rubber powder, tyre fiber and wood powder, were investigated. Experiments were performed at different heating rates of $10,30,45$ and $60^{\circ} \mathrm{C} / \mathrm{min}$. It was observed that there was a significant difference in reaction time and total weight loss in feedstocks. This indicates that different feedstocks exhibit different kinetics during thermal decomposition. Also, it can be understood that feedstocks influence on the kinetics of pyrolysis and combustion.

The influence of tyre formulation on the products of pyrolysis was examined by Lopez et al. [53]. The study was carried out in a conical spouted bed reactor in the temperature range of $425-600^{\circ} \mathrm{C}$. Two kinds of tyre materials with varying compositions of natural and synthetic rubber were used. It was found that products of pyrolysis were not affected by the tyre composition; however it influenced the properties of products drastically.

The above studies indicate that different feedstocks undergo thermal degradation differently. It also implies that feedstock influences the product yield and product properties as well.

\section{Feedstock Particle Size}

Oyedun et al. conducted an optimization study of particle size in waste tyre pyrolysis [54]. The study is more of a simulation study aimed to compare the influence of particle size on the process completion time and overall energy requirement during the decomposition. The particle sizes were studied at varying heating rates and operational strategies. The study confirmed that small particles reached completion within a short span of time, while larger particles consumed less energy. The study validated that the particle size has a profound influence on process operation and product yield.

Barbooti et al. conducted pyrolysis in a fixed bed batch reactor heated by an electrical furnace [55]. The effect of particle size $(2,6$, 10,16 and $20 \mathrm{~mm}$ ) was studied at an optimum nitrogen flow rate of $0.35 \mathrm{~m}^{3} / \mathrm{h}$ and at various temperatures between $400-460^{\circ} \mathrm{C}$. It was found that solid residue yield increased when the particle sizes were increased. However, beyond $16 \mathrm{~mm}$ the carbon black yield remained constant, which indicates that large particles have less impact on carbon black yield. The difference in carbon black yield of larger particles (16 and $20 \mathrm{~mm}$ ) was insignificant. The yield of tyre-oil decreased, initially corresponding to the increase in particle size of feedstock up to $10 \mathrm{~mm}$. However, beyond $10 \mathrm{~mm}$, an increase in the tyre-oil yield was observed. In general, when the particle size is increased, carbon black and tyre-oil yield decreases. The large sized particles block the release of volatiles, and hence more carbon black is generated. Due to reduced availability of volatiles, the generation of tyre-oil is reduced. For to this reason, an increase in carbon black yield and a decrease in tyre-oil yield were observed when the particle size was increased from 2 to $10 \mathrm{~mm}$. However, after $10 \mathrm{~mm}$ (larger size particles) mass transfer limitations come into effect and hence a reversing trend in the yields of carbon black and tyre-oil was noted.

Leung and Wang investigated the effect of particle size on kinetics of scrap tyre pyrolysis and combustion [56]. The kinetics of the process was determined using TGA. Tyre powder of sample sizes 8-16 (between), 16 and $40 \mathrm{~mm}$ was taken and their thermal degradation kinetics were determined between the temperature range of $450-610^{\circ} \mathrm{C}$. For all sample sizes, no change in kinetic energy and frequency factor was found. This indicated that particle size has less impact on decomposition kinetics.

From the above studies, we note that small particles favor for effective conversion. Also, an increase in particle size increases carbon black yield, but it decreases tyre-oil yield. Also, particle size has insignificant influence on the kinetics of pyrolysis and combustion.

\section{Residence Time}

Nkosi and Muzenda reported that liquid and carbon black yield decreased with an increase in vapor residence time [24], but they noted an increase in the gas yield. This could be due to the secondary decomposition of tyre-oils into gases. It was also found that long contact time between carbon black and volatiles decreased the carbon black yield.

The investigation indicated that when vapor residence time is increased, the yield of carbon black and tyre-oil is decreased. Yet, with the increase in residence time, gas yield increases.

\section{Reactor Configuration}

Several reactors such as autoclave, kiln, auger type, fixed bed, 
spouted bed, entrained bed, fluidized bed, rotating cone, vortex type, plasma type, free fall, vacuum pyrolyzer and ablative type have been employed to pyrolyze waste tyres [15,57]. Some prominent works are discussed below.

Martinez et al. conducted co-pyrolysis of forestry wastes and waste tyres in a continuous auger reactor [58]. The thermal inlet power capacity of the reactor was $150 \mathrm{~kW}_{t h}$. Experiments were conducted at a pyrolysis temperature of $500{ }^{\circ} \mathrm{C}$. An inert atmosphere was provided by supplying $\mathrm{N}_{2}$ at a flow rate $5 \mathrm{l} / \mathrm{min}$. Though the reactor was capable of handling $15 \mathrm{~kg} / \mathrm{h}$ of waste tyres, the reactor was operated at a waste tyre feed rate of $5 \mathrm{~kg} / \mathrm{h}$. The study was conducted varying biomass to tyre ratio of 100/0, 90/10, 80/20 and 0/100. The reactor could be able to deliver carbon black yield between 24.97 to $48.31 \%$, tyre-oil yield between 38.38 to $56.01 \%$ and gas yield between 15.88 to $26.54 \%$. Maximum carbon black yield of $48.31 \%$ was obtained at biomass-to-tyre ratio of $0 / 100$. Highest tyre-oil yield of $56.01 \%$ was obtained for the biomass to tyre ratio of $100 / 0$. At biomass-to-tyre ratio of 80/20, maximum gas yield of $26.54 \%$ was attained. It was concluded that the auger reactor yielded tyre-oil of improved quality.

Helleur et al. employed an ablative reactor to pyrolyze used tyres [59]. Experiments were performed at a pyrolysis temperature of $550^{\circ} \mathrm{C}$ under $\mathrm{N}_{2}$ atmosphere. The reactor was designed in such a way that the heating of feedstock to the desired temperature $\left(550^{\circ} \mathrm{C}\right)$ was accomplished within $1 \mathrm{sec}$. This was done to avoid secondary polymerization and condensation reactions. The reactor was successful in achieving complete decomposition and recovering primary pyrolysis products. The generated carbon black had an ash content of $15.2 \%$. When analyzed, it was found that the carbon black was similar to other carbon blacks generated through other pyrolysis technologies. However, it was observed that the carbon black cannot be used in recycling for tire manufacturing and but can be employed in rubber compounding.

An autoclave reactor was attempted by Rodriguez et al. to carry out waste tyre pyrolysis [41]. The volume of the reactor was 3.5 $\mathrm{dm}^{3} . \mathrm{N}_{2}$ gas was passed into the system so as to provide an inert atmosphere. Tyre pieces of size $2-3 \mathrm{~cm}$ were selected for the study. For experimental runs, about $175 \mathrm{~g}$ of tyre pieces was used. The investigation was performed for various pyrolysis temperatures of $300,400,500,600$ and $700{ }^{\circ} \mathrm{C}$. A heating rate of $15^{\circ} \mathrm{C} / \mathrm{min}$ and a solid residence time of $30 \mathrm{~min}$ were maintained throughout the study. The products were obtained in the following range: carbon black yield $43.7-84.7 \%$, tyre-oil yield $4.8-38.5 \%$ and gas yield 7.7 $19.3 \%$. It was found that at pyrolysis temperature of 500, 600 and $700{ }^{\circ} \mathrm{C}$, the decomposition of tyres was complete. Also, a pyrolysis temperature of $500^{\circ} \mathrm{C}$ was the optimum temperature for generation of tyre-oil. At that temperature, the disintegration of tyres was complete and also the pyrolysis process consumed less energy.

Day et al. employed a commercial kiln system for pyrolyzing automobile shredder residue [60]. The commercial system had the capacity to handle $200 \mathrm{~kg} / \mathrm{h}$ of waste tyre. The pyrolysis study was done at $500{ }^{\circ} \mathrm{C}$ and a solid residence time of $15 \mathrm{~min}$. The reactor could deliver a carbon black yield of $43.0 \%$, tyre-oil yield of $31 \%$ and gas yield of $26 \%$. It was concluded that commercial valuable products could be generated from waste tyres.

A conical spouted bed reactor was employed by Lopez et al. for performing continuous pyrolysis of waste tyres [53]. The intention of the study was to investigate the effect of tyre formulation on the composition of pyrolysis products. The study was done using two feeds, such as natural and synthetic rubber. In this study, the pyrolysis temperature was varied at 425,500 and $600^{\circ} \mathrm{C}$. Feedstock was fed at a rate of $300 \mathrm{~g} / \mathrm{h}$. An inert atmosphere was ensured by equipping $\mathrm{N}_{2}$ at a flow rate of $30 \mathrm{l} / \mathrm{min}$. The natural rubber yielded products in the following composition: carbon black 35.36-38.30\%, tyre-oil $54.88-62.83 \%$ and gas $1.81-6.81 \%$. The product composition of $33.91-35.81 \%$ for carbon black yield, 33.91-35.81\% for tyreoil yield and $1.81-8.26 \%$ for gas yield was obtained for synthetic rubber. It was concluded that temperature and tire composition had an insignificant effect on product composition. Nonetheless, both parameters exhibited significant influence on product quality. Further, it was found that the carbon black generated at $600{ }^{\circ} \mathrm{C}$ displayed high surface area and was suitable to be employed as activated carbon.

Roy and Chaala used vacuum pyrolysis of automobile shredder residue in a vacuum pyrolyzer [61]. The reactor was of the following dimensions: volume $15 \mathrm{l}$, length $3 \mathrm{~m}$ and diameter $0.6 \mathrm{~m}$. The reactor was attached to three condensers for effective condensing of volatiles. A feed rate of $50 \mathrm{~kg} / \mathrm{h}$ was maintained. The experiments were conducted at a pyrolysis temperature between 496 to $536{ }^{\circ} \mathrm{C}$ and at pressure between $1-5 \mathrm{kPa}$. The composition of the products was carbon black $52.5 \%$, organic liquids $27.7 \%$, pyrolytic water $13.3 \%$ and gas $6.6 \%$. It was concluded that vacuum pyrolysis offers high flexibility with regard to energy recovery.

Kaminsky and Mennerich conducted pyrolysis of synthetic tire rubber in a laboratory scale fluidized-bed reactor [62]. Quartz sand of particle diameter $0.3-0.5 \mathrm{~mm}$ was used as fluidized bed medium. The study was performed at pyrolysis temperatures of 500, 550 and $600{ }^{\circ} \mathrm{C}$ with a gas residence time of $2.6-3.0 \mathrm{~s}$. With $\mathrm{N}_{2}$ as fluidizing gas, the reactor generated a carbon black yield of 30.00-40.00\%, tyre-oil yield of 51.24-65.59\% and gas yield of 5.0-9.2\% respectively. The study was also conducted with steam as fluidizing gas at $500{ }^{\circ} \mathrm{C}$. It contributed $31.0 \%$ of carbon black yield, $65.0 \%$ of tyre-oil yield and $3.5 \%$ of gas yield. It was found that the quality of the carbon black greatly improved with increase in temperature. The quality of the carbon black was quite good at $600^{\circ} \mathrm{C}$. Also, it was concluded that $\mathrm{N}_{2}$ and steam contributed for the same products (carbon black, tyre-oil and gas) yield.

A laboratory scale entrained flow reactor was experimented by Wojtowicz et al. [63]. The study aimed to generate carbon black from waste tyre pyrolysis oil. The reactor was made of quartz and was heated externally. Four oil samples were tested. Oil droplets of size $\mathrm{d}<20 \mu \mathrm{m}$ was sprayed through a spray nozzle assembly. The reactor was maintained at a temperature of $1,100^{\circ} \mathrm{C}$. Experiments were conducted at carrier gas flow rates of 2,000 and $500 \mathrm{ml} / \mathrm{min}$. Oils were supplied at a flow rate of $0.10-0.16 \mathrm{~cm}^{3} / \mathrm{min}$. The system generated carbon black yield between 25.0 to $60.0 \%$. It was found that the generated carbon black was well within the range of ASTM carbon black.

The above literatures indicate that the configuration of reactors also influence the decomposition of waste tyres. The yield and composition of the pyrolysis products are also influenced by the reactor design. Notwithstanding, during the selection of the reactors fac- 
Table 7. Properties of carbon black from various tyres

\begin{tabular}{|c|c|c|c|c|c|}
\hline Properties & Carbon black 1 & Carbon black 2 & Carbon black 3 & Carbon black 4 & Carbon black 5 \\
\hline $\mathrm{C}$ & & 80.30 & $83.50 \pm 0.50$ & 87.37 & 83.00 \\
\hline $\mathrm{H}$ & & 1.30 & $0.60 \pm 0.040$ & 0.66 & \\
\hline $\mathrm{N}$ & & 0.30 & $0.30 \pm 0.070$ & 0.31 & \\
\hline S & & 2.70 & $2.40 \pm 0.10$ & 2.63 & 2.60 \\
\hline $\mathrm{Zn}$ & & 3.80 & & & 4.20 \\
\hline $\mathrm{O}$ & & & & & 6.00 \\
\hline $\mathrm{Si}$ & & & & & 1.60 \\
\hline $\mathrm{Ca}$ & & & & & 2.40 \\
\hline $\mathrm{HHV}(\mathrm{MJ} / \mathrm{kg})$ & & $29.30 \mathrm{MJ} / \mathrm{kg}$ & $28.80 \pm 0.60$ & & \\
\hline Specific gravity & 1.70 & & & & \\
\hline Bulk density & $519.00 \mathrm{~kg} / \mathrm{m}^{3}$ & & & & \\
\hline Particle size & 40-50 microns & & & & \\
\hline BET surface area & $40.00 \mathrm{~m}^{2} / \mathrm{g}$ & 83.00 & & 82.00 & \\
\hline $\begin{array}{l}\text { CTAB (cetyltrimethylammonium } \\
\text { bromide adsorption methods) } \\
\text { surface area }\end{array}$ & $85.00 \mathrm{~m}^{2} / \mathrm{g}$ & & & & \\
\hline $\begin{array}{l}\text { Void volume DBP } \\
\text { (dibutyl phthalate method) }\end{array}$ & $85.50 \mathrm{ml} / 100 \mathrm{~g}$ & & & & \\
\hline Total pore volume $\left(\mathrm{cm}^{3} / \mathrm{g}\right)$ & & & & 0.40 & \\
\hline Total micropore volume $\left(\mathrm{cm}^{3} / \mathrm{g}\right)$ & & & & $<0.01$ & \\
\hline Average pore size (nm) & & & & 50 & \\
\hline Pellet hardness & $23.00 \mathrm{~g} / \mathrm{pellet}$ & & & & \\
\hline Toluene discoloration & 90.00 & & & & \\
\hline Effective thermal diffusivity & & & $9.00 * 10^{-8} \mathrm{~m}^{2} / \mathrm{s}$ & & \\
\hline Specific heat capacity & & & $1,500 \mathrm{~J} / \mathrm{kg} \mathrm{K}$ & & \\
\hline Thermal conductivity & & & $0.10 \mathrm{~W} / \mathrm{mK}$ & & \\
\hline Reference & CIWMB [11] & Olazar [43] & Rodriguez [41] & Aranda et al. [26] & Nkosi and Muzenda [24] \\
\hline
\end{tabular}

tors such as economics, nature of feedstock, desired products, available resources, etc. should also be well thought out.

\section{Catalyst}

Williams and Brindle studied the effect of catalyst on scrap tyre pyrolysis [64]. Pyrolysis was performed in a semi-continuous fluidized bed reactor at varying temperatures of 450, 500, 550 and $600{ }^{\circ} \mathrm{C}$. Y-type zeolite and zeolite ZSM- 5 catalyst were investigated in this study. In case of tyre-oil yield, the addition of catalyst decreased its yield. At low temperatures of 450 and $500{ }^{\circ} \mathrm{C}, \mathrm{CBV} 400$ catalyst favored tyre-oil yield, while at high temperatures of 550 and $600{ }^{\circ} \mathrm{C}$ ZSM5 favored tyre-oil yield. The addition of catalyst obviously improved gas yield significantly at all temperatures. It was found that CBV 400 effected more gas yield than ZM5 catalyst. Also, the addition of catalyst did not yield any significant change in carbon black yield.

The influence of zeolite USY catalyst on the yield of products was studied by Boxiong et al. [65]. Pyrolysis was carried out in a fixed bed reactor. The result indicated that increasing catalytic temperature and catalyst/tyre ratio, gas yield increases at the expense of tyre-oil yield. The increase in catalyst/tyre ratio from 0.25 to 1.0 increased gas yield from 30.5 to $49.9 \%$. Nonetheless, it decreased tyre-oil yield from 31.6 to $12.7 \%$. No significant change in carbon black yield was noticed with the addition of catalyst.
The above studies indicate that the introduction of catalyst improves gas yield. Nevertheless, catalyst addition reduces tyre-oil yield. It can also be noted that catalyst has no influence on carbon black yield.

\section{PYROLYSIS PRODUCTS}

\section{Carbon Black}

The properties of carbon black from various tyres are presented in Table $7[24,26,38,41,43]$. The standard analysis pertaining to the determination of properties of carbon black is given in Table 4 $[13,23,37,41,66,67]$. Carbon black, as such, has the potential to be used as fuel. Generally, carbon black is used as fuel, adsorbent and precursor to generate activated carbon. In some power plants, carbon black is made into slurry and used as fuels. As adsorbent, tyre derived carbon black is very effective in eliminating pollutants such as chromium, lead, copper, dyes and phenol from industrial liquid effluents $[17,40,68-71]$. It is also used to capture industrial gaseous effluents such as $\mathrm{SO}_{2}[24,72]$. Furthermore, carbon black is used as fillers and pigments for making printing inks, tyres, etc. [73].

Table 8 presents some literatures on the generation of activated carbon from waste tyre pyrolysis [74-76]. Compared to carbon 
Table 8. Works on generation of activated carbon from waste tyre pyrolysis

\begin{tabular}{|c|c|c|c|c|c|}
\hline Reactor & $\begin{array}{l}\text { Parameter } \\
\text { of study }\end{array}$ & Operating conditions & Output & Findings & Reference \\
\hline Activation: TG & Particle size & $\begin{array}{l}\text { Temperature- } 900{ }^{\circ} \mathrm{C}, \text { Heating } \\
\text { rate- } 30^{\circ} \mathrm{C} / \mathrm{min} \text {, Atmo- } \\
\text { sphere- He mixture, Feed- } \\
\text { stock- } 170 \mathrm{mg} \text { piece and } \\
\text { granulated piece of diame- } \\
\text { ter less than } 300 \mu \mathrm{m}\end{array}$ & $\begin{array}{l}\text { Char yield (Granulated tyres)- } \\
36 \% \text {, Surface area } 99\left(\mathrm{~m}^{2} / \mathrm{g}\right) \text { for } \\
0 \% \text { burn-off, } 124\left(\mathrm{~m}^{2} / \mathrm{g}\right) \text { for } \\
30 \% \text { burn-off, } 188\left(\mathrm{~m}^{2} / \mathrm{g}\right) \text { for } \\
50 \% \text { burn-off } \\
\text { Char yield }(170 \mathrm{mg})-34 \% \text {, } \\
\text { Surface area } 97\left(\mathrm{~m}^{2} / \mathrm{g}\right) \text { for } 0 \% \\
\text { burn-off, } 423\left(\mathrm{~m}^{2} / \mathrm{g}\right) \text { for } 30 \% \\
\text { burn-off, } 732\left(\mathrm{~m}^{2} / \mathrm{g}\right) \text { for } 50 \% \\
\text { burn-off }\end{array}$ & $\begin{array}{l}\text { The efficiency of } \\
\text { activation pro- } \\
\text { cess is more for } \\
\text { large sized } \\
\text { feedstock. }\end{array}$ & $\begin{array}{c}\text { Teng et al. } \\
{[74]}\end{array}$ \\
\hline $\begin{array}{l}\text { Pyrolysis: Quartz } \\
\text { tube reactor }\end{array}$ & Temperature & $\begin{array}{l}\text { Feedstock- Natural rubber } \\
\text { tyre, Feed- } 1 \mathrm{~g} \text {, Atmo- } \\
\text { sphere- Helium, Solid resi- } \\
\text { dence time- } 1 \mathrm{hr} \text {, Water feed } \\
\text { rate- } 0.75 \mathrm{mg} \text { of water/g of } \\
\text { sample/s, Temperature- } 700 \\
\text { and } 900{ }^{\circ} \mathrm{C}\end{array}$ & $\begin{array}{l}\text { For temperature } 700{ }^{\circ} \mathrm{C} \text { : Carbon } \\
\text { residue surface area } \sim 100 \mathrm{~m}^{2} / \mathrm{g} \\
\text { For temperature } 900{ }^{\circ} \mathrm{C} \text { : Carbon } \\
\text { residue surface area- } 1260 \mathrm{~m}^{2} / \mathrm{g}\end{array}$ & $\begin{array}{l}\text { Increase in tem- } \\
\text { perature } \\
\text { increases the } \\
\text { surface area of } \\
\text { char residue. }\end{array}$ & $\begin{array}{c}\text { Ogasawara } \\
\text { et al. } \\
{[75]}\end{array}$ \\
\hline $\begin{array}{l}\text { Cylindrical } \\
\text { stainless steel } \\
\text { atmospheric } \\
\text { pressure } \\
\text { reactor }\end{array}$ & $\begin{array}{l}\text { Activation } \\
\text { agent }\end{array}$ & $\begin{array}{l}\text { Feedstock- } 20 \mathrm{~g} \text {, Tempera- } \\
\text { ture- } 750-900{ }^{\circ} \mathrm{C} \text {, Activa- } \\
\text { tion time- } 1-3 \mathrm{~h} \text {, Activation } \\
\text { agent- steam and } \mathrm{CO}_{2}\end{array}$ & $\begin{array}{l}\text { Activated carbon- } 1317 \mathrm{~m}^{2} / \mathrm{g} \text { at } \\
\quad 900{ }^{\circ} \mathrm{C} \text { in steam } \\
\text { Activated carbon- } 496 \mathrm{~m}^{2} / \mathrm{g} \text { at } \\
\quad 850^{\circ} \mathrm{C} \text { in } \mathrm{CO}_{2}\end{array}$ & $\begin{array}{l}\text { Activation using } \\
\text { steam gener- } \\
\text { ates activated } \\
\text { carbon with } \\
\text { narrow microp- } \\
\text { ores and large } \\
\text { surface area. }\end{array}$ & $\begin{array}{c}\text { Gonzalez } \\
\text { et al. } \\
{[76]}\end{array}$ \\
\hline
\end{tabular}

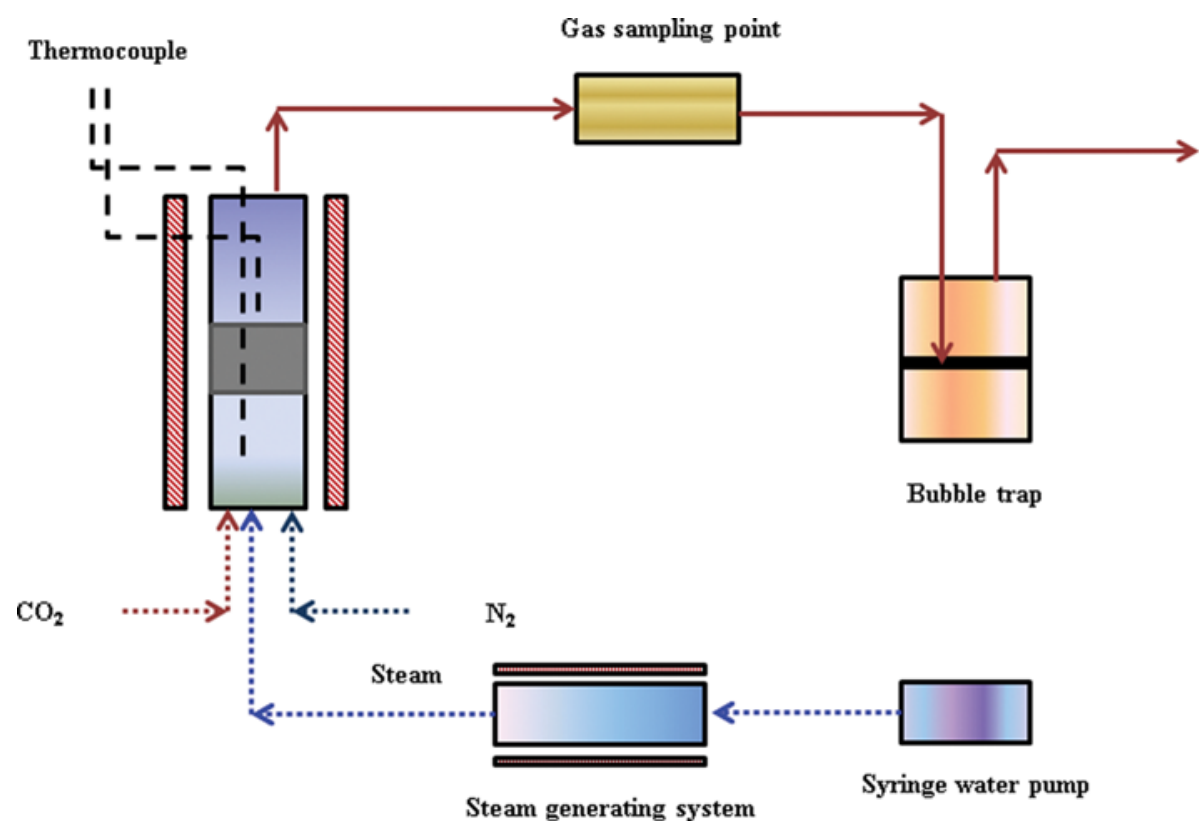

Fig. 2. Schematic illustration of generation of activated carbon from carbon black.

black, activated carbon has a good commercial market. The commercial potential of carbon black can be improved by converting carbon black into activated carbon, which can be done through chemical activation. A schematic of carbon black conversion into activated carbon is presented in Fig. 2 [77]. Even though activation agents such as steam or carbon dioxide are used, the carbon generated from steam displays good surface area [73,77]. When steam is used as activating agent, it reacts with carbon of carbon 
Table 9. Properties of activated carbon from various tyres

\begin{tabular}{|c|c|c|c|c|c|}
\hline Properties & Activated carbon 1 & Activated carbon 2 & Activated carbon 3 & Activated carbon 4 & Activated carbon 5 \\
\hline $\mathrm{C}$ & 87.00 & 80.25 & 84.90 & 96.80 & \\
\hline $\mathrm{O}$ & 5.90 & 7.62 & 13.60 & $<0.10$ & \\
\hline $\mathrm{H}$ & & & 0.08 & 0.22 & \\
\hline $\mathrm{N}$ & & & 0.80 & 0.22 & \\
\hline $\mathrm{Si}$ & 0.60 & 4.13 & & & \\
\hline$S$ & 1.80 & 1.01 & 0.60 & 5.85 & \\
\hline $\mathrm{Zn}$ & 2.90 & & & & \\
\hline $\mathrm{Ca}$ & 1.80 & & & & \\
\hline $\mathrm{Fe}$ & & 3.11 & & & \\
\hline Surface area & 800 & $400 \mathrm{~m}^{2} / \mathrm{g}$ & & $373 \mathrm{~m}^{2} / \mathrm{g}$ & $1317 \mathrm{~m}^{2} / \mathrm{g}$ \\
\hline Meso volume & & & & & $1.25 \mathrm{~cm}^{3} / \mathrm{g}$ \\
\hline Macro volume & & & & & $0.47 \mathrm{~cm}^{3} / \mathrm{g}$ \\
\hline Reference & Nkosi and Muzenda [24] & Belgacem et al. [78] & López et al. [79] & Wójtowicz et al. [80] & González et al. [76] \\
\hline
\end{tabular}

black and generates hydrogen, carbon monoxide, carbon dioxide and methane. With carbon dioxide as agent, the activation process releases carbon monoxide. The reaction between carbon black and agent generates gases by disintegration of carbon black particles, thereby increasing the surface area of carbon black.

Table 9 presents properties of activated carbon [24,76,78-80]. Activated carbons are mostly used as adsorbents to adsorb phenols, basic dyes, metals, p-chlorophenols, butane, natural gas, etc. $[24,81,82]$. They are also effective in the removal of organic as well as inorganic substances from industrial effluents. Specifically, $\mathrm{KOH}$ activated carbon is used to remove halogenated hydrocarbons and pesticides from drinking water $[24,47,81]$. Of late, activated carbon is applied in gas phase applications too $[18,24,58,76,81]$. They find their application in the separation, storage and catalysis of gaseous species. They are also used for the transportation of flammable gases such as acetylene, etc.

\section{Tyre-oil}

Tyre-oil is dark brown and has an acrid smell. The property of the oil is presented in Table $10[4,19,44,83,84]$. The standard analysis concerned with the determination of properties of tyre-oil is given in Table $4[1,4,15,16,42,47,83,85-88]$. The oil can be directly used as fuel in furnaces, steam boilers, gas turbines, IC engines, etc. [24]. Oil can be treated to derive some important chemicals such as benzene, xylene, toluene and D-limonene [57,64,73,89].

Table 10. Properties of tyre-oil from various tyres

\begin{tabular}{|c|c|c|c|c|c|}
\hline Proximate analysis & Tyre-oil 1 & Tyre-oil 2 & Tyre-oil 3 & Tyre-oil 4 & Tyre-oil 5 \\
\hline \multicolumn{6}{|l|}{ Ultimate analysis } \\
\hline Carbon & 86.5 & & & 84.09 & 60.32 \\
\hline Hydrogen & 10.8 & & & 9.75 & 6.94 \\
\hline Nitrogen & 0.5 & & & 0.39 & 0.35 \\
\hline Sulfur & 0.8 & 0.6 & 0.55 & 1.37 & 0.14 \\
\hline Ashes & Traces & & & & \\
\hline Oxygen & 2.2 & & & 4.40 & 32.25 \\
\hline $\mathrm{Cl}(\mathrm{ppm})$ & 130 & & & & \\
\hline \multicolumn{6}{|l|}{ Heating value } \\
\hline LHV (MJ/kg) & & 43.1 & $41.0 @ 25^{\circ} \mathrm{C}$ & & \\
\hline GCV (MJ/kg) & 43.7 & 45.9 & $42.1 @ 25^{\circ} \mathrm{C}$ & 41.31 & 25.6 \\
\hline \multicolumn{6}{|l|}{ Physical properties } \\
\hline Carbon conradson residue & 1.3 & & & & \\
\hline Density $\left(\mathrm{kg} / \mathrm{m}^{3}\right)$ & $950 @ 20^{\circ} \mathrm{C}$ & 840 & 872.7 & 994.7@15 ㄷ & 876.3@15 ํㅡ \\
\hline Viscosity $40^{\circ} \mathrm{C}$ (cs) & $9.7 @ 50^{\circ} \mathrm{C}$ & 2.35 & 5.2 & $6.61 @ 50^{\circ} \mathrm{C}$ & $1.99 @ 40^{\circ} \mathrm{C}$ \\
\hline Flash point $\left({ }^{\circ} \mathrm{C}\right)$ & 28 & 38 & 64 & & $<30$ \\
\hline Freezing point $\left({ }^{\circ} \mathrm{C}\right)$ & & & -11.5 & & \\
\hline Boiling range $\left({ }^{\circ} \mathrm{C}\right)$ & & $110-300$ & $80-320$ & & \\
\hline Diesel index & & & 49 & & \\
\hline Reference & Roy et al. [83] & Shah et al. [44] & Shah et al. [84] & Kar [19] & Uçar and Karagöz [86] \\
\hline
\end{tabular}


These chemicals are important feedstock for manufacturing plastics, resins, fibers, dyestuffs, pesticides, solvents, surfactants, etc. [47]. Upon upgradation, tyre-oil can also be converted into useful transport fuel.

Earlier studies on recovery of Limonene from tyre-oil are presented in Table 11 [57,72,90-92]. D-limonene is one such essential chemical which can be derived from tyre-oil. The schematic of Dlimonene recovery from tyre-oil is illustrated in Fig. 3 [16]. Recently, the generation of $\mathrm{D}$-Limonene from tyre-oil has been picking up.
D-Limonene has become an inevitable commodity in the formulation of many solvents, resins, adhesives, etc. [42,64,93,94]. It is used as a dispersing agent in pigments and fragrance agent in cleaning products $[42,94,95]$. It is used in pharmaceutical industry in the formulation of drugs used for curing cancer, bronchitis etc. [19]. In food industry, it is employed as a flavoring agent in making beverages and chewing gum. Due to its increased usage in industries such as pharmaceutical, chemical and cosmetic, its demand is increasing every year $[24,90]$. The extraction of D-Limonene from

Table 11. Works on recovery of Limonene from tyre-oil

\begin{tabular}{|c|c|c|c|c|}
\hline Reactor & Operating conditions & Output & Findings & Reference \\
\hline $\begin{array}{l}\text { Multiple hearth } \\
\text { vacuum } \\
\text { pyrolysis } \\
\text { unit }\end{array}$ & $\begin{array}{l}\text { Pyrolysis: } \\
\text { Temperature- } 510{ }^{\circ} \mathrm{C} \text {, Pressure- } 1 \mathrm{kPa} \text {, Feed- } \\
3.5 \mathrm{~kg} / \mathrm{h} \\
\text { Distillation: } \\
\text { Pressure- Atmospheric, Temperature- } \\
204^{\circ} \mathrm{C} \text {. }\end{array}$ & $\begin{array}{l}\text { Tyre-oil- } 55.0 \% \\
\text { Limonene- } 95.0 \% \\
\text { purity }\end{array}$ & $\begin{array}{l}\text { High purity Limonene can } \\
\text { be generated from tyre-oil }\end{array}$ & $\begin{array}{l}\text { Pakdel et al. } \\
\text { [72] }\end{array}$ \\
\hline $\begin{array}{l}\text { Continuous } \\
\text { ablative reac- } \\
\text { tor }\end{array}$ & $\begin{array}{l}\text { Pyrolysis: } \\
\text { Temperature- } 550^{\circ} \mathrm{C} \text {, Residence time- } 0.6 \mathrm{~s} \text {, } \\
\text { Atmosphere- Nitrogen, Feed size- } 1 \mathrm{~cm} \\
\text { Distillation: } \\
\text { Temperature- } 190^{\circ} \mathrm{C} \text {. }\end{array}$ & $\begin{array}{l}\text { Limonene- } 16.3 \% \\
\quad \text { (Vacuum distillation) } \\
\text { Limonene- 32.0-37.0\% } \\
\quad \text { (Re-distillation) }\end{array}$ & $\begin{array}{l}\text { Vacuum distillation is the } \\
\text { apt method to purify } \\
\text { Limonene. }\end{array}$ & $\begin{array}{l}\text { Stanciulescu } \\
\text { and Ikura } \\
\text { [92] }\end{array}$ \\
\hline $\begin{array}{l}\text { Fixed-bed fire } \\
\text { tube heating }\end{array}$ & $\begin{array}{l}\text { Pyrolysis: } \\
\text { Temperature- } 375,425,475,525 \text { and } \\
575^{\circ} \mathrm{C} \text {, Heating rate- } 15^{\circ} \mathrm{C} / \mathrm{min} \text {, Atmo- } \\
\text { sphere- } \mathrm{N}_{2} \text {, Feed size- } 4 \mathrm{~cm}^{3}\end{array}$ & $\begin{array}{l}\text { Highest liquid yield- } \\
\quad 475^{\circ} \mathrm{C} \\
\text { Limonene- } 50.86 \%\end{array}$ & $\begin{array}{l}\text { The property of tyre-oil is } \\
\text { very similar to petroleum } \\
\text { derived fuels. }\end{array}$ & $\begin{array}{l}\text { Rofiqul et al. } \\
\text { [91] }\end{array}$ \\
\hline $\begin{array}{l}\text { Analytical } \\
\text { pyrolyzer } \\
\text { with GC/MS }\end{array}$ & $\begin{array}{l}\text { Pyrolysis: } \\
\text { Temperature- } 500,550,600,650 \text { and } \\
700{ }^{\circ} \mathrm{C} \text {, Heating rate- } 20^{\circ} \mathrm{C} / \mathrm{ms} \text {, Feed size- } \\
\text { less than } 100 \text { mesh, Residence time- } 20 \mathrm{~s}\end{array}$ & $\begin{array}{l}\text { Maximum Limonene } \\
\text { yield- } 22.9 \%\end{array}$ & $\begin{array}{l}\text { Maximum Limonene yield } \\
\text { is possible at tempera- } \\
\text { tures less than } 500^{\circ} \mathrm{C} \text {. }\end{array}$ & $\begin{array}{l}\text { Ding et al. } \\
\text { [57] }\end{array}$ \\
\hline $\begin{array}{l}\text { Semi-continu- } \\
\text { ous pilot } \\
\text { plant reactor }\end{array}$ & $\begin{array}{l}\text { Pyrolysis: } \\
\text { Temperature- } 440-570{ }^{\circ} \mathrm{C} \text {, Feed rate- } 21 \\
\text { and } 42 \mathrm{~kg} / \mathrm{h}\end{array}$ & $\begin{array}{l}\text { Maximum Limonene } \\
\text { yield- } 50.0 \%\end{array}$ & $\begin{array}{l}\text { Beyond } 500{ }^{\circ} \mathrm{C} \text { Limonene is } \\
\text { decomposed. }\end{array}$ & $\begin{array}{l}\text { Pakdel et al. } \\
\text { [90] }\end{array}$ \\
\hline
\end{tabular}

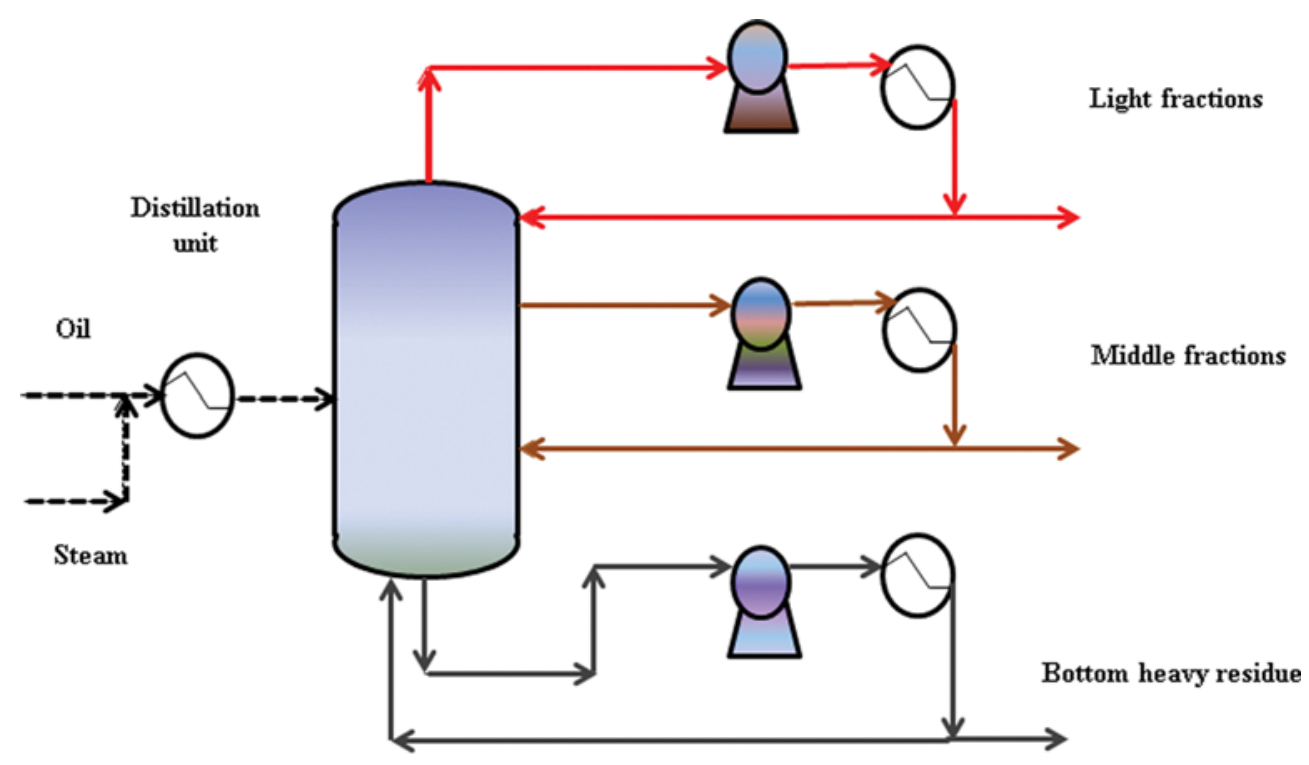

Fig. 3. Recovery of D-Limonene from tyre-oil. 
Table 12. Composition of tyre-syngas reported in literatures

\begin{tabular}{|c|c|c|c|c|c|c|c|c|c|c|}
\hline \multirow{2}{*}{ Constituent } & \multicolumn{2}{|c|}{ Tyre-syngas 1} & \multicolumn{2}{|c|}{ Tyre-syngas 2} & \multicolumn{2}{|c|}{ Tyre-syngas 3} & \multicolumn{2}{|c|}{ Tyre-syngas 4} & \multicolumn{2}{|c|}{ Tyre-syngas 5} \\
\hline & (Vol\%) & $(\mathrm{Wt} \%)$ & (Vol\%) & $(\mathrm{Wt} \%)$ & (Vol\%) & $(\mathrm{Wt} \%)$ & (Vol\%) & (Wt\%) & (Vol\%) & $(\mathrm{Wt} \%)$ \\
\hline $\mathrm{H}_{2}$ & 6.5 & 0.66 & 2.3 & 0.14 & 10.097 & 0.179 & 20.0 & 1.78 & & \\
\hline CO (\%) & 1.3 & 1.84 & 43.9 & 37.19 & 0.382 & 0.095 & 29.0 & 35.93 & 11.94 & 7.86 \\
\hline $\mathrm{CO}_{2}(\%)$ & 1.6 & 3.56 & 41.8 & 55.63 & 1.177 & 0.460 & & & 8.39 & 8.67 \\
\hline $\mathrm{CH}_{4}(\%)$ & 10.8 & 8.77 & 9.6 & 4.66 & 5.427 & 0.771 & 1.7 & 1.21 & 1.94 & 0.73 \\
\hline $\mathrm{C}_{2} \mathrm{H}_{6}(\%)$ & 4.3 & 6.54 & 0.9 & 0.82 & 1.557 & 0.415 & & & 10.00 & 7.06 \\
\hline $\mathrm{C}_{2} \mathrm{H}_{4}(\%)$ & 4.5 & 6.39 & 0.9 & 0.76 & 1.152 & 0.286 & & & 5.81 & 3.83 \\
\hline $\mathrm{C}_{2} \mathrm{H}_{2}(\%)$ & & & & & 0.000 & & & & & \\
\hline $\mathrm{C}_{3} \mathrm{H}_{8}(\%)$ & 5.1 & 11.38 & 0.6 & 0.80 & 0.660 & 0.258 & & & 3.55 & 3.68 \\
\hline $\mathrm{C}_{3} \mathrm{H}_{6}(\%)$ & 4.8 & 10.22 & & & 0.872 & 0.325 & & & & \\
\hline $\mathrm{C}_{4} \mathrm{H}_{10}(\%)$ & & & & & 0.165 & 0.085 & & & 5.16 & 7.04 \\
\hline $\mathrm{C}_{4} \mathrm{H}_{8}(\%)$ & & & & & 0.102 & 0.050 & & & & \\
\hline Isobutyene (\%) & & & & & 2.090 & 1.039 & & & & \\
\hline Butadiene (\%) & & & & & 0.120 & 0.057 & & & & \\
\hline Cis-pentene (\%) & & & & & 0.035 & 0.022 & & & & \\
\hline n-Hexane (\%) & & & & & 0.040 & 0.030 & & & & \\
\hline Cyclohexane (\%) & & & & & 0.355 & 0.264 & & & & \\
\hline Benzene (\%) & & & & & 0.083 & 0.057 & & & & \\
\hline Isobutane & & & & & & & & & 0.00 & 0.00 \\
\hline Isobutene & & & & & & & & & 0.65 & 0.86 \\
\hline 1,3 Butadiene & & & & & & & & & 37.74 & 47.95 \\
\hline 2-Butene & & & & & & & & & 9.35 & 12.32 \\
\hline $\mathrm{H}_{2} \mathrm{~S}$ & 0.5 & 0.86 & & & & & & & & \\
\hline Heating value & & & $11.4 \mathrm{I}$ & $\mathrm{Nm}^{3}$ & & & $6.4 \mathrm{I}$ & $\mathrm{Nm}^{3}$ & & \\
\hline Reference & Martíne & al. [15] & Martíne & al. [33] & Berruec & al. [96] & Martíne & al. [58] & Olazar & al. [43] \\
\hline
\end{tabular}

tyre-oil offers a tremendous scope.

3. Gas

The gas contains good heating value and is used to supply process heat [38]. Composition of tyre-syngas reported in the literature is presented in Table 12 [15,33,43,58,96].

\section{WASTE TYRE RECYCLING PLANTS}

There are many waste tyre recycling plants all over the world. Table 13 details some of the commercial waste tyre recycling plants in the world. Lately, new plants are being commissioned in fast grow-

Table 13. Some commercial waste tyre recycling plants of the world

\begin{tabular}{|c|c|c|c|c|}
\hline Plant & Location & Product & Purpose & $\begin{array}{l}\text { Capacity }^{*} \\
(\mathrm{~T} / \mathrm{yr})\end{array}$ \\
\hline Lakin Tire East/West & California, USA & Crumb rubber & $\begin{array}{l}\text { Tyre derived aggregate, rubberized asphalt, tyre } \\
\text { derived fuel, recycled consumer products }\end{array}$ & 387600 \\
\hline $\begin{array}{l}\text { Laking General } \\
\text { Corporation }\end{array}$ & Chicago, USA & $\begin{array}{l}\text { Tyre derived fuel } \\
\text { (TDF), Crumb tyre }\end{array}$ & Automotive parts, mats, Fuels & 306000 \\
\hline Emanuel Tire, LLC & Maryland, USA & Crumb rubber & $\begin{array}{l}\text { Civil engineering materials, rubber reclaim } \\
\text { industry material, septic system material, } \\
\text { sound wall material, horse arena footing, } \\
\text { playground material, tyre derived fuel }\end{array}$ & 173400 \\
\hline Liberty Tire recycling & $\begin{array}{l}23 \text { Facilities across } \\
\text { USA }\end{array}$ & $\begin{array}{l}\text { Crumb rubber, TDF, } \\
\text { rubber mulch }\end{array}$ & $\begin{array}{l}\text { Mats, rail road ties, anti-fatique mats, acoustical } \\
\text { underlay, portable speed bumps, weightlift- } \\
\text { ing plates, Astroturf, Fuel, automotive parts, } \\
\text { paints and coatings, house foundation, land- } \\
\text { scaping and playground applications }\end{array}$ & 113500 \\
\hline Genan & Houston, Texas, USA & Rubber powder & Asphalt, Bitumen & 100000 \\
\hline
\end{tabular}


Table 13. Continued

\begin{tabular}{|c|c|c|c|c|}
\hline Plant & Location & Product & Purpose & $\begin{array}{l}\text { Capacity" } \\
\text { (T/yr) }\end{array}$ \\
\hline Genan & Viborg, Denmark & Rubber powder & Asphalt, Bitumen & 70000 \\
\hline Genan & $\begin{array}{l}\text { Kammlach, Bayern, } \\
\text { Germany }\end{array}$ & Rubber powder & Asphalt, Bitumen & 70000 \\
\hline Genan & $\begin{array}{l}\text { Oranienburg, Berlin, } \\
\text { Germany }\end{array}$ & Rubber powder & Asphalt, Bitumen & 65000 \\
\hline Genan & $\begin{array}{l}\text { Dorsten, NRW } \\
\text { Germany }\end{array}$ & Rubber powder & Asphalt, Bitumen & 65000 \\
\hline Eldan recycling & $\begin{array}{l}\text { Al ain, Abu Dhabi, } \\
\text { UAE }\end{array}$ & Granulate & TDF & 57600 \\
\hline $\begin{array}{l}\text { Crumb rubber } \\
\text { manufacturers }\end{array}$ & California, USA & Crumb rubber & $\begin{array}{l}\text { Rubberised asphalt, sports tracks, mulch, rub- } \\
\text { ber molded products }\end{array}$ & 51000 \\
\hline $\begin{array}{l}\text { Champlin Tire } \\
\text { recycling, Inc. }\end{array}$ & Concordia, USA & Crumb Tyre & Park benches and picinic tables & 40800 \\
\hline Entech, Inc. & White pigeon, USA & Crumb rubber & $\begin{array}{l}\text { Molding, extrusion, rubberized asphalt, eques- } \\
\text { trian markets, mulch and playgrounds }\end{array}$ & 36320 \\
\hline L \& S Tire Company & Washington, USA & TDF, Crumb tyre & Fuel, tyre bales, tyre treads, retreads & 35700 \\
\hline $\begin{array}{l}\text { Tire disposal \& } \\
\text { Recycling Inc. }\end{array}$ & Portland, USA & TDF, crumb tyre & $\begin{array}{l}\text { Fuel, cicil engineering applications, grading of } \\
\text { casings for re-use }\end{array}$ & 10200 \\
\hline $\begin{array}{l}\text { AngloEnvironmental } \\
\text { Engineering \& } \\
\text { Construction Limited }\end{array}$ & Essex, UK & Tyre blocks & Civil construction & 1500 \\
\hline $\begin{array}{l}\text { S \& J Granulate Solutions } \\
\text { Pvt. Ltd. }\end{array}$ & Gujarat, India & Rubber granulates & $\begin{array}{l}\text { Flooring- Sports stadium, Insulation, Hoses- } \\
\text { irrigation }\end{array}$ & 1500 \\
\hline
\end{tabular}

${ }^{*}$ Capacity calculated based on one piece of tyre is equivalent to $10.2 \mathrm{~kg}$ of tyre chips

ing developing countries.

\section{CONCLUSION}

This review paper addresses the nuisances of and need to treat these waste tyres. The article emphasis is on the energy recovery routes from waste tyres. Even though three means of energy recovery exist, only pyrolysis and gasification are largely employed to generate carbon black, tyre-oil and syngas from waste tyres. Variables such as temperature, heating rate, feedstock, feedstock particle size, residence time, reactor configuration, catalyst, majorly influence the product composition of pyrolysis. There exists a huge potential to generate value added products, such as activated carbon and limonene.

\section{FUTURE SCOPE}

Tyres upon thermal decomposition are prone to release pollutants such as $\mathrm{SO}_{2}, \mathrm{H}_{2} \mathrm{~S}, \mathrm{HCl}, \mathrm{HCN}$, dioxins $\left(\mathrm{C}_{4} \mathrm{H}_{4} \mathrm{O}_{2}\right)$ and polycyclic aromatic hydrocarbons (PAH). Hence, future research should focus on arresting these pollutants.

Carbon black from waste tyres is considered of low quality as they contain impurities as high as $10 \%$. Hence, suitable treatments to reduce the impurities need to be explored.

Though activated carbon from waste tyres satisfy the criteria of commercial activated carbon (surface area close to $500 \mathrm{~m}^{2} /$ g), its market demand is not that much sound. Henceforth, some appropriate upgradation techniques to increase the surface area of activated carbon have to be established.

$>$ The economics involved in the extraction of limonene from tyre-oil is expensive. The production cost can be brought down by optimizing operating conditions such as usage of apt reactors, temperature, heating rate, vapor residence time, catalyst, etc. Further research should investigate on these parameters to optimize the cost of production of limonene.

\section{ACKNOWLEDGEMENTS}

This work was supported by the New \& Renewable Energy of the Korea Institute of Energy Technology Evaluation and Planning (KETEP) grant funded by the Korea government Ministry of Knowledge Economy (No. 20143010091790). This work was supported (in part) by the Yonsei University Research Fund of 2015.

\section{NOMENCLATURE}

API : American petroleum institute

ASTM : American society for testing and materials

BET : brunauer emmett teller

$\mathrm{CTAB}$ : cetyltrimethylammonium bromide adsorption methods

DBP : dibutyl phthalate method

DCN : derived cetane number 
DT : derivative thermogravimetric

EN ISO : european union ISO

ER : equivalence ratio

EU : european union

GC : gas chromatography

GC/MS : gas chromatography/mass spectrometry

HFRR : high-frequency reciprocating rig

$\mathrm{HHV}$ : higher heating value

HTR : high temperature reactor

IC : internal combustion

ICP-AES : inductively coupled plasma atomic emission spectroscopy

ISO : international organization for standardization

Ltd. : limited

OAN : oil absorption number

$\mathrm{PAH}$ : polycyclic aromatic hydrocarbons

Pvt. : private

TAN : total acid number

TDF : tire derived fuel

TG : thermogravimetric

UAE : United Arab Emirates

UK : United Kingdom

USA : United States of America

XRF :X-ray fluorescence

\section{REFERENCES}

1. S. Uçar, S. Karagöz, J. Yanik, M. Saglam and M. Yuksel, Fuel Process. Technol., 87, 53 (2005).

2. A. Gulzad, Recycling and pyrolysis of scrap tire, Traning Visit Report, Kabul Polytechnic University, Kabul, Afghanistan (2011).

3. Y. Su and B. Zhao, Pyrolysis of waste tire powder and its comparison with Shenhua Coal, in International Conference on Energy and Environment Technology, 262 (2009).

4. S. Uçar and S. Karagöz, Fuel, 137, 85 (2014).

5. Y. Su and W. Deng, A thermogravimetric study of waste tire powder, in 2010 International Conference on E-Product E-Service and E-Entertainment (ICEEE), Henan, 1 (2010).

6. J. Jang, T. Yoo, J. Oh and I. Iwasaki, Resour. Conserv. Recycl., 22, 1 (1998).

7. A. Quek and R. Balasubramanian, J. Anal. Appl. Pyrolysis, 101, 1 (2013).

8. S. Rani, Int. J. Mater. Sci. Appl., 3(5), 164 (2014).

9. B. Adhikari, D. De and S. Maiti, Prog. Polym. Sci., 25(7), 909 (2000).

10. E. Muzenda, A comparative review of waste tyre pyrolysis, gasification and liquefaction (PGL) processes, in International Conference on Chemical Engineering Advanced Computational Technologies (2014).

11. CIWMB, California Integrated waste management Board (1996).

12. USEPA, Scrap tires, United States Environmental Protection Agency, 2014. [Online]. Available: http://www.epa.gov/osw/conserve/materials/tires/basic.htm. [Accessed: 05-Nov-2015].

13. K. Unapumnuk, M. Lu and T. C. Keener, Ind. Eng. Chem. Res., 45(26), 8757 (2006).

14. R. Murillo, M. V. Navarro, J. M. López, T. García, M. S. Callén, E. Aylón and A. M. Mastral, J. Anal. Appl. Pyrolysis, 71(2), 945 (2004).
15. J. D. Martínez, R. Murillo, T. García and A. Veses, J. Hazard. Mater., 261, 637 (2013).

16. M. Rofiqul Islam, H. Haniu and M. Rafiqul Alam Beg, Fuel, 87(1314), 3112 (2008).

17. M. Miranda, I. Cabrita, F. Pinto and I. Gulyurtlu, Fuel, 103, 542 (2013).

18. O. Senneca, P. Salatino and R. Chirone, Fuel, 78(13), 1575 (1999).

19. Y. Kar, Waste Manag., 31(8), 1772 (2011).

20. P. Straka and Z. Bucko, Fuel Process. Technol., 90(10), 1202 (2009).

21. P. T. Williams, Waste Manag., 33(8), 1714 (2013).

22. ETRMA, End of life tyres: A valuable resource with growing potential, Brussels, Belgium (2011).

23. S. Bhadra, P. P. De, N. Mondal, R. Mukhapadhyaya and S. D. Gupta, J. Appl. Polym. Sci., 89(2), 465 (2003).

24. N. Nkosi and E. Muzenda, A review and discussion of waste tyre pyrolysis and derived products, in Proceedings of the World Congress on Engineering 2014 Vol II (WCE 2014) (2014).

25. JATMA, Tyre industry of Japan, 2012 (2011).

26. A. Aranda, R. Murillo, T. García, M. S. Callén and A. M. Mastral, Chem. Eng. J., 126(2-3), 79 (2007).

27. M. Bajus and N. Olahová, Pet. Coal, 53(2), 98 (2011).

28. T. Amari, N. J. Themelis and I. K. Wernick, Resour. Policy, 25(3), 179 (1999).

29. P. Basu, Biomass gasification and pyrolysis practical design, First. Oxford, Elsevier Ltd. (2010).

30. S. Portofino, A. Donatelli, P. Iovane, C. Innella, R. Civita, M. Martino, D. A. Matera, A. Russo, G. Cornacchia and S. Galvagno, Waste Manag., 33(3), 672 (2013).

31. M. Gu, H. Dong, X. Liu and J. Li, Study on the combustion behavior of pulverized coal and waste tyre by TG-FTIR, in Asia-Pacific Power and Energy Engineering Conference, APPEEC, 1 (2010).

32. S. Galvagno, S. Casu, M. Martino, E. Di Palma and S. Portofino, J. Therm. Anal. Calorim., 88(2), 507 (2007).

33. J. D. Martínez, R. Murillo, T. García and I. Arauzo, Energy Convers. Manag., 81, 338 (2014).

34. E. Aylón, a. Fernández-Colino, M. V. Navarro, R. Murillor, T. García and a. M. Mastral, Ind. Eng. Chem. Res., 47(12), 4029 (2008).

35. H. Liu, B. Feng, J. Lu and C. Zheng, Chem. Eng. Commun., 192(11), 1482 (2005).

36. J. Lee, J. Kim and J. Kim, Energy, 28(6), 575 (2003).

37. M. Banar, A. Özkan, V. Akyıldız, Z. Çokaygil and Ö. Onay, J. Mater. Cycles Waste Manag., 17(1), 125 (2015).

38. CIWMB, Environmental factors of waste tire pyrolysis, gasification, and liquefaction, California (1995).

39. E. R. Raj, R. Z. Kennedy and B. C. Pillai, Energy Convers. Manag., 67, 145 (2013).

40. S. G. Miguel, G. D. Fowler and C. J. Sollars, Ind. Eng. Chem. Res., 37(97), 2430 (1998).

41. I. Rodriguez, M.F. Laresgoiti, M. A. Cabrero, A. Torres, M. J. Chomón and B. Caballero, Fuel Process. Technol., 72(1), 9 (2001).

42. A. M. Cunliffe and P. T. Williams, J. Anal. Appl. Pyrolysis, 44(2), 131 (1998).

43. M. Olazar, R. Aguado, M. Arabiourrutia, G. Lopez, A. Barona and J. Bilbao, Energy Fuels, 22(5), 2909 (2008).

44. J. Shah, M. Rasul Jan and F. Mabood, Iran J. Chem. Chem. Eng., 27(2), 103 (2008) 
45. T. Araki, N. Kiikawa, H. Hosoda, H. Nishizaki and S. Mitsui, Conserv. Recycl., 3(2), 155 (1979).

46. J.D. Martínez, N. Puy, R. Murillo, T. García, M. V. Navarro and A. M. Mastral, Renew. Sustain. Energy Rev., 23, 179 (2013).

47. N. Antoniou and A. Zabaniotou, Renew. Sustain. Energy Rev., 20, 539 (2013).

48. X. Dai, X. Yin, C. Wu, W. Zhang and Y. Chen, Energy, 26(4), 385 (2001).

49. J. F. González, J. M. Encinar, J. L. Canito and J. J. Rodríguez, J. Anal. Appl. Pyrolysis, 58-59, 667 (2001).

50. D. Y. C. Leung, X. L. Yin, Z. L. Zhao, B. Y. Xu and Y. Chen, Fuel Process. Technol., 79(2), 141 (2002).

51. D. Pradhan and R. K. Singh, Int. J. Chem. Eng. Appl., 2(5), 332 (2011).

52. D. Y. C. Leung and C. L. Wang, Fuel Process. Technol., 84(1-3), 175 (2003).

53. G. Lopez, M. Olazar, M. Amutio, R. Aguado and J. Bilbao, Energy Fuels, 23(11), 5423 (2009).

54. A. Oyedun, K. L. Lam, M. Fittkau and C. W. Hui, Fuel, 95, 417 (2012).

55. M. M. Barbooti, T. J. Mohamed, A. A. Hussain and F. O. Abas, J. Anal. Appl. Pyrolysis, 72(1), 165 (2004).

56. D. Y. Leung and C. Wang, J. Anal. Appl. Pyrolysis, 45(2), 153 (1998).

57. K. Ding, Z. Zhong, B. Zhang, Z. Song and X. Qian, Energy Fuels, 29(5), 3181 (2015).

58. J. D. Martínez, A. Veses, A. M. Mastral, R. Murillo, M. V. Navarro, N. Puy, A. Artigues, J. Bartrolí and T. García, Fuel Process. Technol., 119, 263 (2014).

59. R. Helleur, N. Popovic, M. Ikura, M. Stanciulescu and D. Liu, J. Anal. Appl. Pyrolysis, 58-59, 813 (2001).

60. M. Day, J. D. Cooney and Z. Shen, J. Anal. Appl. Pyrolysis, 37(1), 49 (1996).

61. C. Roy and A. Chaala, Resour. Conserv. Recycl., 32(1), 1 (2001).

62. W. Kaminsky and C. Mennerich, J. Anal. Appl. Pyrolysis, 58-59, 803 (2001).

63. M. A. Wójtowicz, R. Bassilakis and M. A. Serio, Carbon black derived from waste tire pyrolysis oil, Advanced Fuel Research, Inc., 2004. [Online]. Available: https://www.researchgate.net/profile/ Michael_Serio/publication/238102979_CARBON_BLACK_DERIVED_FROM_WASTE_TIRE_PYROLYSIS_OIL/links/00b7d52ec1d7b067f3000000.pdf?inViewer=0\&pdf)sDownload=0\&origin =publication_detail. [Accessed: 03-Dec-2015].

64. P. T. Williams and A. J. Brindle, Environ. Technol., 24(7), 921 (2003). 65. S. Boxiong, W. Chunfei, L. Cai, G. Binbin and W. Rui, J. Anal. Appl. Pyrolysis, 78(2), 243 (2007).

66. A. M. Cunliffe and P. T. Williams, Energy Fuels, 13(1), 166 (1999).

67.Z. Koreňová, M. Juma, J. Annus, J. Markoš and L. Jelemenský, Chem. Pap., 60(6), 422 (2006).

68. N. K. Hamadi, X. D. Chen, M. M. Farid and M. G. Q. Lu, Chem. Eng. J., 84(2), 95 (2001).

69. G. San Miguel, G. D. Fowler and C. J. Sollars, Carbon N. Y., 41(5), 1009 (2003).

70. P. Ariyadejwanich, W. Tanthapanichakoon, K. Nakagawa, S. R. Mukai and H. Tamon, Carbon N. Y., 41(1), 157 (2003).
71. M. Streat, J. W. Patrick and M. J. Comporro Perez, Water Res., 29(2), 467 (1995).

72. H. Pakdel, C. Roy, H. Aublin, G. Jean and S. Coulombe, Environ. Sci. Technol., 25(9), 1646 (1991).

73. S.-Q. Li, Q. Yao, Y. Chi, J.-H. Yan and K.-F. Cen, Ind. Eng. Chem. Res., 43(1), 5133 (2004).

74. H. Teng, M. A. Serio, M. A. Wojtowicz, R. Bassilakis and P. R. Solomon, Ind. Eng. Chem. Res., 34, 3102 (1995).

75. S. Ogasawara, M. Kuroda and N. Wakao, Ind. Eng. Chem. Res., 26(12), 2552 (1987).

76. J. F. González, J. M. Encinar, C. M. González-García, E. Sabio, A. Ramiro, J. L. Canito and J. Gañán, Appl. Surf. Sci., 252(17), 5999 (2006).

77. G. López, M. Olazar, M. Artetxe, M. Amutio, G. Elordi and J. Bilbao, J. Anal. Appl. Pyrolysis, 85(1-2), 539 (2009).

78. A. Belgacem, M. Belmedani, R. Rebiai and H. Hadoun, Chem. Eng. Trans., 32, 1705 (2013).

79. F. A. López, T. A. Centeno, O. Rodríguez and F. J. Alguacil, J. Air Waste Manage. Assoc., 63(5), 534 (2013).

80. M. A. Wójtowicz, E. Florczak, E. Kroo and M. A. Serio, Activated Carbon From Waste Tires for Mercury Emissions Control, 2004 (2004).

81. E. L. K. Mui, D. C. K. Ko and G. McKay, Carbon N. Y., 42(14), 2789 (2004).

82. M. Juma, Z. Koreňová, J. Markoš, L. Jelemensky and M. Bafrnec, Polym. Adv. Technol., 18, 144 (2007).

83. C. Roy, A. Chaala and H. Darmstadt, J. Anal. Appl. Pyrolysis, 51(12), 201 (1999).

84. J. Shah, M. R. Jan and F. Mabood, J. Polym. Environ., 15(3), 207 (2007).

85. F. Paradela, F. Pinto, A. M. Ramos, I. Gulyurtlu and I. Cabrita, J. Anal. Appl. Pyrolysis, 85(1-2), 392 (2009).

86. S. Ucar, S. Karagoz, A. R. Ozkan and J. Yanik, Fuel, 84(14-15), 1884 (2005).

87. A.-M. Al-Lal, D. Bolonio, A. Llamas, M. Lapuerta and L. Canoira, Fuel, 150, 208 (2015).

88. P. T. Williams, R. P. Bottrill and A. M. Cunliffe, Process Saf. Environ. Prot., 76(4), 291 (1998).

89. B. Acevedo, C. Barriocanal and R. Alvarez, Fuel, 113, 817 (2013).

90. H. Pakdel, D. M. Pantea and C. Roy, J. Anal. Appl. Pyrolysis, 57(1), 91 (2001).

91. I. M. Rofiqul, H. Haniu and A. B. M. Rafiqul, J. Environ. Eng., 2(4), 681 (2007).

92. M. Stanciulescu and M. Ikura, J. Anal. Appl. Pyrolysis, 75(2), 217 (2006).

93. M. Arabiourrutia, G. Lopez, G. Elordi, M. Olazar, R. Aguado and J. Bilbao, Chem. Eng. Sci., 62(18-20), 5271 (2007).

94. M. R. Islam, M. U.H. Joardder, S. M. Hasan, K. Takai and H. Haniu, Waste Manag., 31(9-10), 2142-9 (2011).

95. M. R. Islam, M. Parveen, H. Haniu and M. R. I. Sarker, Int. J. Environ. Sci. Dev., 1(1), 89 (2010).

96. C. Berrueco, E. Esperanza, F. J. Mastral, J. Ceamanos and P. GarcíaBacaicoa, J. Anal. Appl. Pyrolysis, 74, 245 (2005). 